\title{
THE CLIMATE FOR CHANGE
}

The conditions for effective climate change policies: A case study on residential home insulation policies in New Zealand and Germany

by

Oliver Lah

Thesis

ENVIRONMENTAL STUDIES 593

2009
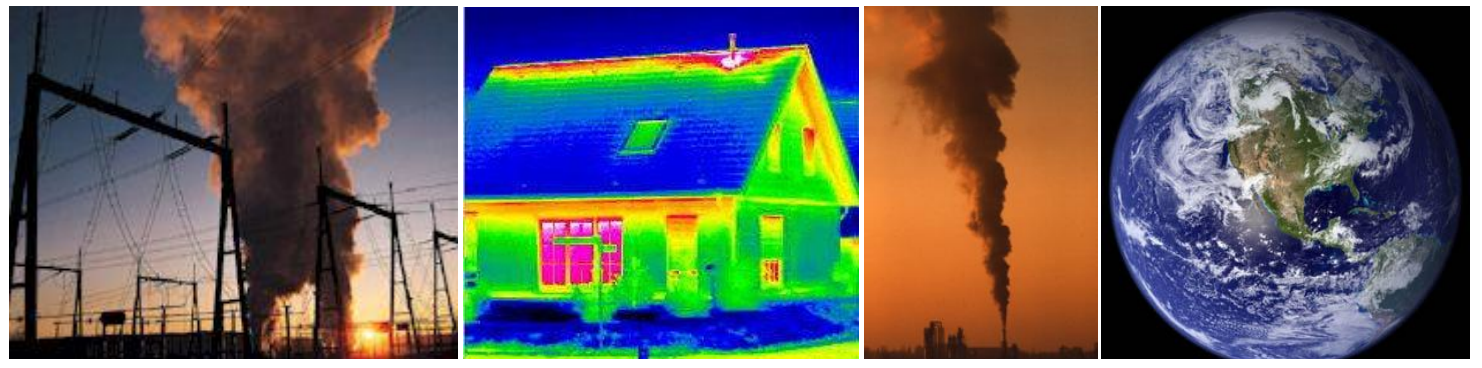

A 90 point thesis submitted to Victoria University of Wellington

in partial fulfilment of the requirements for the degree of

Master of Environmental Studies

School of Geography, Environment and Earth Sciences

Victoria University of Wellington

(June, 2009) 


\title{
THE CLIMATE FOR CHANGE
}

The conditions for effective climate change policies: A case study on residential home insulation policies in New Zealand and Germany.

\section{Oliver Lah}

\begin{abstract}
Changes in the global climate and the insecure future of the world's energy supply place unprecedented risks and uncertainties before mankind. Massive changes need to occur, driven by effective policies. But what is the ideal climate for change? With a case study on insulation policies for the residential building sector this thesis aims to identify the conditions for a climate for change.

This thesis explores the factors that help or hinder change and the structures that enable change and enhance implementation. Within a particular policy area, i.e. residential home insulation, this thesis examines the impacts on policy development and implementation of environmental and resources pressures, the strength of centre-left and green parties and the levels of corporatism in New Zealand and Germany. The case study of insulation policies in New Zealand and Germany has been chosen because of similar policy aspirations and rhetoric in the two countries but differing policy achievements and outcomes. The thesis compares three decades of policy making and implementation in Germany and New Zealand and finds that, if environmental and resource pressures are high, corporatist structures may impact positively on climate change policy development and implementation. It also finds that in pluralist countries centre-left and green party strength may be more important for the success of climate change policies than in corporatist countries.
\end{abstract}

Key words: climate change; energy security; corporatism; Germany; New Zealand 


\section{Acknowledgments}

I want to thank everyone who helped me with this thesis, in particular my two supervisors, Associate Professor Ralph Chapman and Dr John Leslie. This was a very nice piece of teamwork, thanks Ralph and John! I also want to thank the offices of Tim Barnett MP and Josip Juratovic MdB, in particular Gareth Hancock and Isabel Straka for giving me access to the archives of the New Zealand House of Representatives and the German Bundestag. I am in debt to Martin Bury and Tim Barnett for giving me political insights. And also many thanks to Mike Birds and Hillary Tempest for proofreading. Thanks to the European Union Studies Centres Network, Sarah Coleman and Professor Martin Holland for granting me a course fees scholarship. And a very special thanks to my family, Barbara, Sophia and Noah Lah for invaluable support. 


\section{Contents}

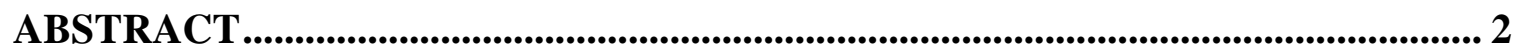

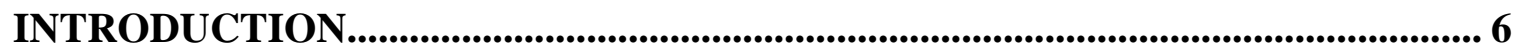

Why it is important: the role of energy efficiency in the context of energy security and climate change ........................................................... 7

Why markets fail: The collective action problem in a climate change policy

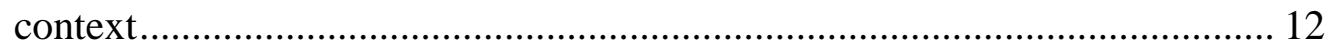

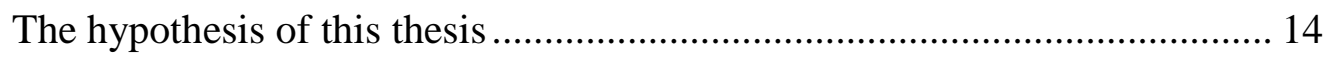

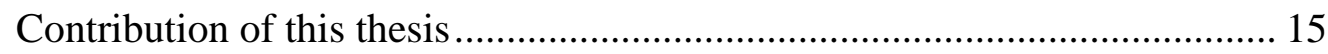

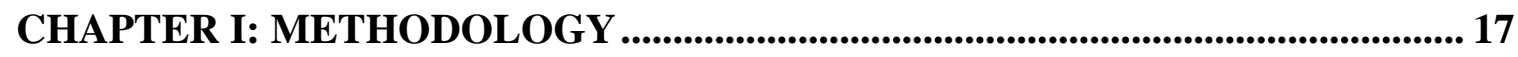

The policy area: energy efficiency ..................................................... 17

The factors for a 'climate for change' .................................................. 18

The countries: New Zealand and Germany ............................................. 21

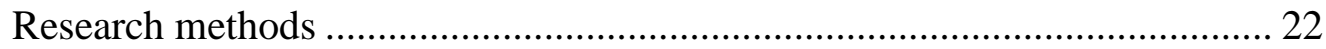

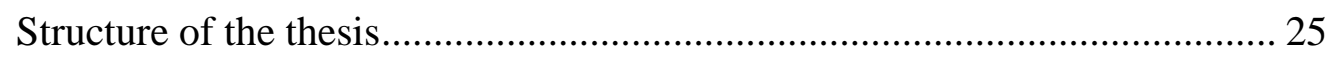

CHAPTER II: EVIDENCE BASE ........................................................................... 26

Heating energy efficiency in residential buildings in Germany and New

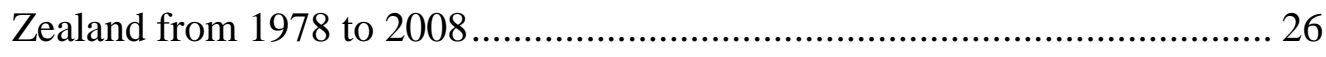

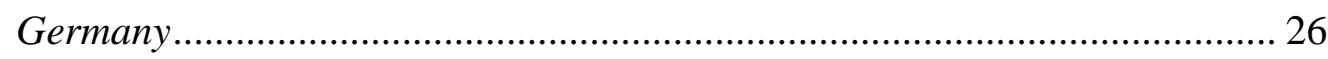

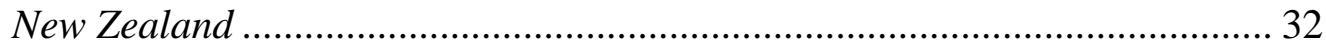

\section{CHAPTER III: RESIDENTIAL HOME INSULATION POLICIES IN} GERMANY

Coalitions and oppositions: how policies emerged................................. 42

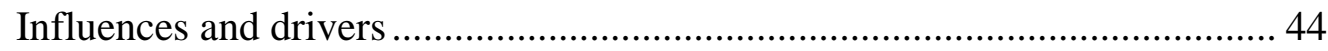

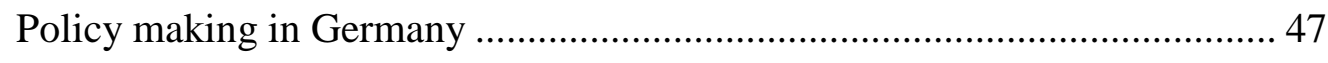

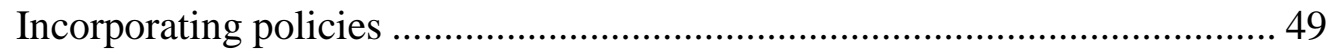

Continuity in corporatist Germany ...................................................... 51 


\section{CHAPTER IV: RESIDENTIAL HOME INSULATION POLICIES IN}

NEW ZEALAND

Coalitions and oppositions: how policies emerged.................................. 53

Influences and drivers .................................................................. 55

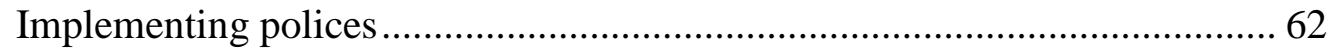

Lack of continuity in pluralist New Zealand ......................................... 64

CHAPTER V: FINDINGS AND IMPLICATIONS ......................................... 66

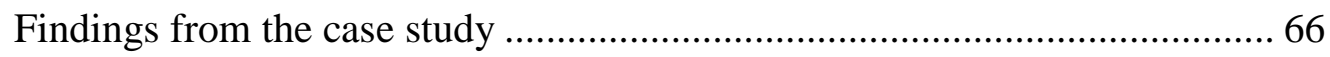

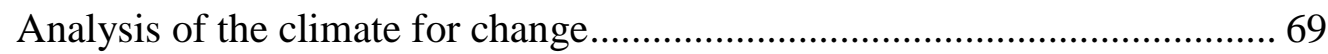

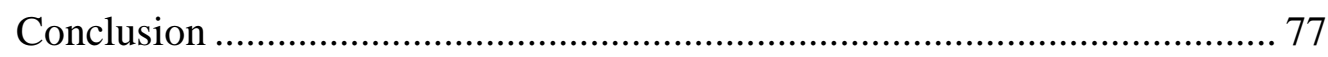

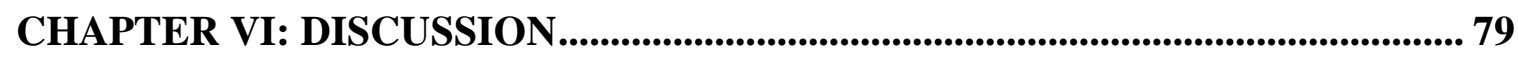

How does the conclusion relate to the findings of the literature?................. 79

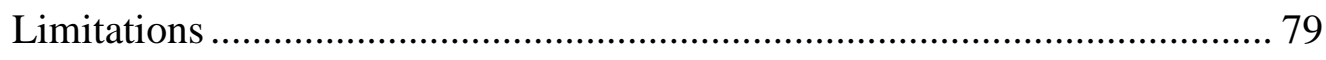

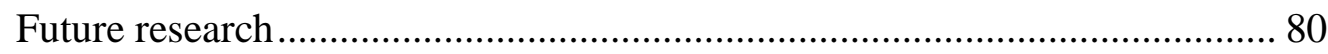

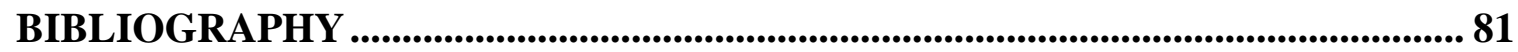

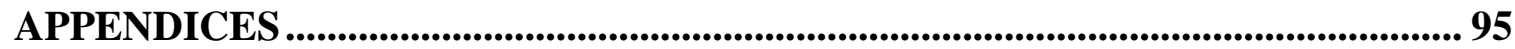




\section{INTRODUCTION}

This thesis aims to identify beneficial conditions for a 'climate for change'.

The main questions for the thesis are: What factors can promote policies that mitigate anthropogenic climate change? And what structures can help in developing and implementing climate change policies? To get a clear picture, this thesis focuses on a specific example within the broader portfolio of climate change policies. It scrutinizes the case of residential home insulation policies in Germany and New Zealand over a period of thirty years. That includes the policy development, the standards themselves, schemes and other supporting measures and the achieved outcomes. The outcomes will be the starting point of this thesis; we then proceed backwards to examine the differences in the developments in the two countries to find an explanation for outcome differences. The two countries examined in this thesis differ significantly in their levels of resource pressures and corporatism but have had similar political constellations over the last three decades. A comparison between the two countries helps illuminate the possible link between corporatism and these policies and outcomes. Furthermore I examine whether and how resource and environmental pressures, or the lack of such pressures, helps or hinders policy development. The first chapter will lay out the conceptual framework and hypotheses and explain the methodology. The second chapter will focus on the policy outcomes i.e. energy performance improvement in residential home space heating over the last thirty years and the number and quality of amendments to minimum insulation requirements in the two countries. The following two chapters explore Germany and then New Zealand, focussing on policy development, coalition building, interest groups and other influencing factors, beginning from the 1970s oil price shocks until recent years. The last chapters summarise the findings and discuss them against the hypothesis. 


\section{Why it is important: the role of energy efficiency in the context of energy security and climate change}

As the International Energy Agency points out, "energy efficiency is by far the most effective way to fulfil the three major energy related challenges: increased energy security, reduced energy costs and a cleaner environment" (IEA 2008a). Energy efficiency policies have already delivered significant benefits as without policy intervention implemented since the 1970s oil price

shocks worldwide energy consumption would be more than $50 \%$ higher today than it is (IEA 2004). But there is still a huge potential for efficiency to be improved to match the challenges of surging energy demand, high energy prices and climate change.

A significant part of the challenge is to reduce energy consumption of buildings, which are estimated to account for over $40 \%$ of the world's total primary energy consumption and for $24 \%$ of the world's $\mathrm{CO}_{2}$ emissions (IPCC 2007a). Even though the efficiency potential of the residential sector is significant, a large proportion of the potential improvement in the existing housing stock is still unexploited, despite proven cost effective measures (Gaterell and McEvoy 2005; Chapman et al. 2008).

There are various factors responsible for that suboptimal development, such as difficulties in gaining access to capital, comparatively low priority of energy issues, principal-agent problems, and untargeted incentives. Those problems encapsulate obstacles in overcoming the initial cost barrier as well as individual level barriers in moving towards adequate action, and result in slow progress towards a more energy efficient housing stock.

\section{Potential and importance of energy efficiency}

Roughly one third of the world's energy is used for its intended purpose, while about two thirds is lost as a result of inefficiencies in energy production, transport and consumption (Houghton 2004). Improved energy efficiency can 
lower the world's energy consumption by about 17 to $33 \%$ by 2030 and even then, there remains large potential for further energy efficiency improvements (IEA 2006; IPCC 2007b). However, responses to climate change are often criticised as being in competition with economic opportunities and impacting negatively on economic growth. In light of these concerns, there is a huge potential for measures that not only pay for themselves but also reduce costs. This so called 'negative cost abatement potential' represents $35-45 \%$ of the total abatement potential below 40 Euro/t $\mathrm{CO}_{2}$, in developed countries (Figure $1)$.

Figure 1 Marginal abatement costs

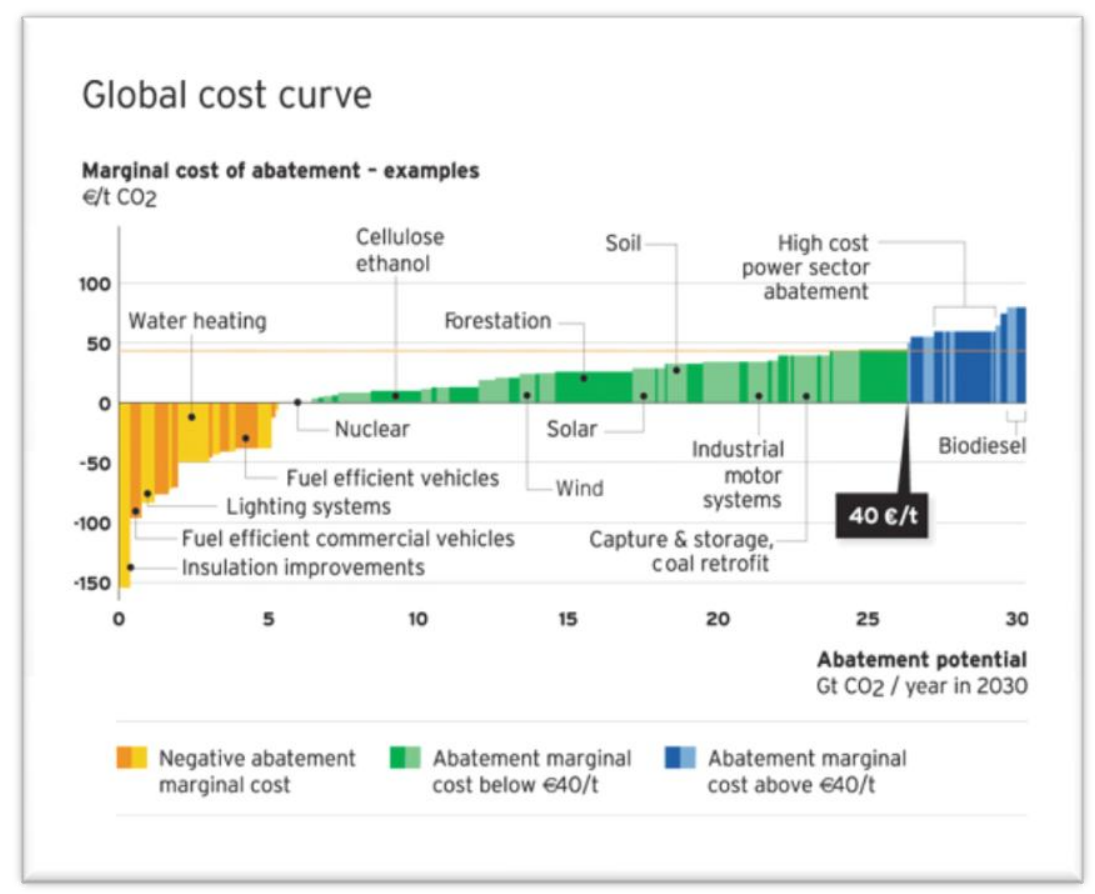

Source: Vattenfall

As shown in Figure 1 efficiency gains from insulation improvements offer significant potential at highest negative abatement cost. Investments in insulation are estimated to have a negative cost of up to 150 Euro ( 300NZD) per ton carbon dioxide avoided (Vattenfall 2008).

Hence home insulation would theoretically create the situation in which socially rational behaviour, the installation of insulation, would lead to a 
benefit for the whole society, the decrease of energy consumption and also an emission reduction.

Energy performance of buildings is a crucial part of the aim to improve efficiency, reduce consumption and greenhouse gas emissions. Even if the gains in energy security and the reduced impact on the global climate are not taken into account, energy efficiency policies "would pay for themselves" (IEA 2006). On average, an additional dollar invested in more efficient appliances or buildings avoids two dollars on the supply side (Wong et al. 2007). On the global scale this means that investment in more efficient enduse appliances and buildings of about US\$2.4 trillion is more than outweighed by the about US\$3 trillion of avoided investment on the supply side and saved fuel and energy costs for consumers of US\$8.1 trillion (IEA 2006). Payback periods are very short and range from one to eight years and are even shorter in developing countries (IEA 2008a).

Thermal insulation is one key measure to achieve higher efficiency rates in residential buildings. ${ }^{1}$ It is a practical and efficient intervention that can have an immediate impact on emission reductions but also offers benefits such as personal comfort, noise control, and condensation control and fire protection. The potential for improved energy efficiency can be described vividly by sketching a building standard that is increasingly used for a green building construction, the so called Passiv Haus (passive house) of which about 6000 have been built already, mainly in central and northern Europe (IEA 2002; Feist 2005). Passive houses consume about 70 to $80 \%$ less than comparable conventional houses and can be built at almost the same cost (Andersen/Dokka 2006). They are heated throughout by the sun and by their inhabitants and have no heating or cooling installations at all but reach mean temperatures of $21.4^{\circ} \mathrm{C}$ in a cold German winter and seldom more than $25^{\circ} \mathrm{C}$

\footnotetext{
${ }^{1}$ Insulation measures for walls ceiling and under floor derive from substances such as fibreglass, rock wool, and mineral wool, foam and other materials primarily designed to reduce the heat transfer through building structures. Efficient glazing usually consists of two to three layers of glass and a non-metallic frame that avoids heat bridges.
} 
in a hot summer (Ebel et al. 1995). This building standard is increasingly popular in many countries worldwide. But building technology goes already beyond the efficiency potential of passive houses to zero-heating-energy buildings and energy plus houses, which generate more energy, for example with photovoltaic, than they consume (Feist 2005).

\section{Barriers and obstacles}

Industrialised countries and an increasing number of emerging countries are considering energy efficiency as a core part of their national energy policies in order to achieve economic gains by using valuable energy resources more efficiently and therefore decouple growth from environmental pressures. Most OECD countries need $30 \%$ less energy today to generate one unit of GDP than 1973 (Geller et al. 2006), when the first oil price shock initiated a more thoughtful treatment of fossil fuel resources. Improvements in the transport sector, in industrial processes, in appliances and space heating made the usage of energy much more efficient over the last three decades. However, overall energy consumption is still increasing worldwide and will continue to increase over the next two decades under a business as usual scenario (IEA 2008b). That raises the question of the effectiveness of these policy measures. The most significant obstacles and critiques are discussed in the following sections to measure the challenges for political action and draw conclusions about the nature of policies that are needed to overcome these barriers.

\section{Rebound/takeback effect}

One issue most energy efficiency measures face is the so called rebound or takeback effect. With regard to policy planning it is suggested that ignoring or underestimating this effect leads to overstated forecasts and expectation on the outcome of the policy and can also contradict payback calculations significantly (WEC 2008). The effect itself refers to the tendency for energy 
demand not to fall significantly, as a result of energy efficiency improvements, because the cost of energy services declines (Geller 2005). One of the most typical examples from residential space heating refers to a situation when insulation measures fail to lead to the desired reduction in energy consumption for heating purposes, since efficiency gains are 'taken back' an increase in personal comfort from higher indoor temperatures.

Behavioural changes such as raising thermostat levels because insulation makes heating more worthwhile or operating energy efficient appliances longer or more often may erode a considerable share of the efficiency gains. Some authors even suggest that energy efficiency improvements can result in an increase of energy consumption, which means that the rebound effects outpace the efficiency gains (Khazzoom 1987; Inhaber 1997; Brookes 2000). This claim has yet to be proved, but a number of studies show that the rebound effect is indeed an issue that needs to be dealt with, while developing effective energy efficiency policies (Binswanger 2001; Sorrell 2007). The rebound effect that can be expected when energy efficiency measures are implemented ranges from 0 to $12 \%$ for appliances, such as fridges and washing machines and lighting, to up to $20 \%$ in industrial processes and 10 to $50 \%$ in residential heating and cooling (IEA 1998). Relevant factors include base temperatures, habits and incomes levels (Howden-Chapman et al. 2009). The comparatively high rebound effect in the residential space heating and cooling sector is one reason for choosing energy efficiency policies in this particular area for the case study. The higher the potential rebound effect in general and also the wider the range of possible takeback ${ }^{2}$ the less certain is the cost effectiveness and the efficiency outcome in terms of conserved energy. This brings up the next major obstacle that needs to be overcome, the financial investment barrier. It is still the most prevalent obstacle to the widespread market penetration of energy efficient products (Sorell et al. 2009).

\footnotetext{
${ }^{2}$ Efficiency gains from residential space heating are more likely to be offset by an increase in personal comfort, than the efficiency gains from a more energy efficient fridge, which practically offers no scope for takeback.
} 


\section{The financial barrier}

The initial cost barrier is a major issue not only in the residential building sector. Even very small appliances such as light bulbs face that obstacle even though the price difference between about one dollar for an incandescent light bulb and about three dollars for a compact fluorescent light bulb is only small and information about payback is widespread (Levine 2006). In this case three pluralist countries, Australia, Ireland and (until the change of government in late 2008) New Zealand were at the forefront in using policy mechanisms to ban traditional light bulbs, following a rather corporatist policy approach (Gormley 2008; Garrett 2008; Parker 2008). Policy makers in these countries concluded that the market was not achieving the desired outcome by itself and considered the banning of this inefficient technology as the only way to foster considerable improvement in a part of the energy sector that accounts for about $19 \%$ of the world's electricity consumption (IEA 2006).

The uptake of an investment in home insulation, with costs ranging roughly between 3,000 and $\$ 30,000^{3}$ is correspondingly harder to encourage simply because of the cost barrier involved (BMVBS 2008b; Cosgrove 2007). On the other hand, the barrier to a basic home insulation retrofit (roughly \$3000) is not insurmountable, especially with a modicum of government assistance. This brings us to the question of why governments might intervene to help.

\section{Why markets fail: The collective action problem in a climate change policy context}

"Freedom in a commons brings ruin to all". Hardin's bold résumé in his influential essay, The Tragedy of the Commons (1968), brings up the question of what kind of institutional framework is needed to govern the commons

\footnotetext{
${ }^{3}$ If not stated otherwise dollar or \$ refers to New Zealand dollar.
} 
properly. Hardin himself claimed that only state established institutional arrangements such as a centralized government and private property would be able to sustain common goods over a long period of time. This has been repeatedly criticised as an oversimplification (McCay 1987; Dietz et al. 2003; Ostrom 2002). And indeed it has been proved that "herders" - to use the metaphor again - are capable of managing resources by developing and maintaining self-governing institutions (Ostrom 1990). This can be seen in a number of examples at the local, national and international level, representing a spectrum from fishing quotas for lakes to emission trading schemes. The personal motivations and political will to achieve collective action are aligned in many ways (Olson 1965). Each individual tends to be driven by rational behaviour and therefore favours the most cost effective choice, even though it may be morally reprehensible (Diamond 2005). In the case of global climate change each perpetrator can be relatively certain of getting away with his bad behaviour, for example heating with coal instead of wood, as long as there is no regulation against it. This represents the typical social dilemma situation, which discourages individuals from cooperating as they can freeride on the contributions of others. The climate change social dilemma occurs where individuals choose actions in an interdependent situation, in this case causing emissions. Atmospheric pollution is a tragedy of the commons in a reverse way. It is not the situation of taking something out of the commons but putting something into the common atmosphere, namely carbon dioxide. Using Garrett Hardin's picture, there are more than 6 billion herdsmen using the "pasture" atmosphere and each one of them as a rational being seeks to maximize his gain. Each usage of the open "pasture" increases personal wealth, in terms of this thesis a heated home, similar to the added cattle to the herd. Each rational individual concludes that the only sensible course for him to pursue is to increase his carbon footprint or at least not to reduce it (Llewellyn 2007; Stern 2007). That locks individuals into a system that forces bad behaviour as good behaviour would be punished by, for example, wasting time on the bus or paying higher prices through offsetting emissions from a flight. The energy consumer is a generally rational acting individual as 
pointed out earlier. However each individual acts differently. Governing the commons means also coping with the different habits of its users (Dietz 2003, Stern et al. 2002).

\section{The hypothesis of this thesis}

As pointed out earlier, improving energy efficiency is a socially cost-effective measure to mitigate climate change and increase energy security. After identifying the barriers to this measure the questions arise: What policies achieve change; i.e. what factors matter in creating a 'climate for change'? The hypothesis of this thesis is that three factors have a significant influence on that: environmental and resource pressures, the level of corporatism and the strength of centre-left and green parties.

It is hypothesised that a relatively high level of domestic environmental and resource pressures is required to initiate policies and to sustain effective measures that support these policies (Tainter 1988; Diamond 2005). This notion is based on the straightforward argument that resource pressures percolate through into the political system to create political impetus for change. As real energy prices rise for example, we might generally expect to see political support for efficiency policies to expand.

A high level of corporatism may also influence the implementation and improvement of these long-term policies, according to the hypothesis. There are a number of elements which may support this, for example: comparatively encompassing interest groups, the 'shadow of state regulation' and a broad acceptance of government regulation due to a history of strong penetration of the state in areas such as the labour market and social policy (Scruggs 1999). I will make the claim that corporatism is beneficial for climate change policy development and outcomes but only if the encompassing groups have vital interests that foster environmentally sustainable policies. In the case of home insulation, interest groups include environmental groups, tenant associations, health associations, landlord organisations and builders' associations. These 
groups are integrated into the policy process in a corporatist country and broaden the basis of policies, which creates a high level of continuity that is required for long-term investments such as home insulation. This coalition building locks groups into certain policy directions that further enhance policy progress, which is almost self-reinforcing (Katzenstein 1977; 1987).

It is also hypothesised that the strength of centre-left parties and green parties is influential of policies and policy outcomes in the domain of interest for this thesis. According to this, policy measures to promote and support residential home insulation are more likely to be introduced by centre-left governments and are more likely to appear on the political agenda, when green parties are well represented in Parliament (Neumayer 2003; Bernauer 2008). Conversely, I would expect that no or only little improvements of insulation standards and supporting schemes are undertaken by centre-right governments. The case study of insulation policies in New Zealand and Germany has been chosen because the two countries exhibit differing environmental and resource pressures and levels of corporatism ${ }^{4}$, but similar strength of centre-left and green parties, and the two countries have a mixed-member proportional (MMP) system. I would expect that there is some difference in the importance of centre-left and green party strength between corporatist and pluralist countries (Liphart 1999), but this is not central to my hypothesis.

\section{Contribution of this thesis}

There are a number of studies examining the influence of corporatism and centre-left and green party strength on environmental performance. They tend to have a broader focus on air pollution or environmental performance in

\footnotetext{
${ }^{4}$ Siaroff (1999) measures the degree of German corporatism as the third highest in the OECD (with a constant figure of 4.125 from 1980 to 1999) behind Austria and Finland. New Zealand was rated at 2.125 over the 1980 s with a slightly increasing level of corporatism in the 1990s with 2.375 (on a scale of 1-5, with 5 being the highest).
} 
general (Lundquist 1980; Scruggs 1999, 2001; Jordan 2005), which for my purposes is too broad a sweep, and also neglects other factors that influence policy making, such as environmental and resource pressures. This study focuses on the specific case of residential home insulation in order to disentangle drivers that influence policy development and outcomes. The approach this thesis takes also allows the illumination on nuances in political attitudes, policy makers' perceptions of different institutional structures and aims to demonstrate causal connections between various factors and policy outcomes. 


\section{CHAPTER I: METHODOLOGY}

The thesis starts from the collective action problem that underlies climate change policies (Stern 2006) and tries to identify factors that help policies to address this problem effectively. I focus on residential energy efficiency in particular.

The specific policy area was chosen partly because it is one that is relatively uncontroversial politically compared to other climate change policies, such as support for emissions trading or renewable energies. Home insulation could be a real success story of multiple benefits for people, climate and the economy, but it is only partially so. The thesis tries to identify the reasons for that.

\section{The policy area: energy efficiency}

In order to sketch policy outcomes in corporatist Germany and pluralist New Zealand the thesis uses quantitative data on residential home energy efficiency and heating energy over a time period of thirty years.

Energy efficiency improvements can generate a return comparatively quickly, particularly for those measures which are just changes in behaviour and where costs are modest or negligible. Improving energy efficiency is considered as offering a wide range of co-benefits for the environment, economy and society (Lovins 1996; IEA 2008a). In particular residential home energy efficiency improvements offer a number of rewards for the investor, such as: an increase in personal comfort and health, reduced $\mathrm{CO}_{2}$ emissions and good payback rate, i.e. a reasonably attractive potential financial benefit over time (Chapman et al. 2009). Nonetheless, energy efficiency needs political assistance because some of these benefits are shared by the individual with society. As noted earlier, energy efficiency represents a clear example of a collective action problem within the climate change context. The collective action problem appears to be obvious in regard to greenhouse gas emissions from personal activity (Ostrom 
1990), as discussed later. According to my hypothesis, three factors create a climate for change that allows this collective action problem to be overcome.

\section{The factors for a 'climate for change'}

\section{Environmental and resource pressures}

The first part of the hypothesis is that a high level of environmental and energy resource pressures enhances the attractiveness and cost-effectiveness of energy efficiency policies. The impact of resource constraints, in particular the 1970s and later oil price shocks and price hikes are part of what may influence policy (Meadows et al. 1972). The dependence on foreign energy resources and the potential to exploit domestic resources will be one important element in this regard. Another element of this factor is the importance of environmental policies on the policy agenda and the way in which the climate change debate has progressed. The emphasis of the analysis will be on fossil fuel resource pressures and the perception of climate change as a policy issue, rather than direct impacts of climate change itself on Germany and New Zealand. Both countries have not suffered from climate change impacts over most of the time frame examined to the extent some that other countries have (IPCC 2007), which is the reason for focusing more on the political perception rather than actual environmental pressures that lead to change or fail to do so (Diamond 2005).

Referring to Garrett Hardin's Tragedy of the Commons (Hardin 1968) and the need to govern the commons (Ostrom 1992, 2002; Olson et al. 2002) the question arises: how do societies respond to resource and environmental pressures, and when? According to the hypothesis they act late and only if the environmental and resource pressures are intense enough. A number of authors even suggest that societies act too late or not at all (Tainter 1988, Gunderson and Holling, 2002; Diamond 2005). 


\section{Corporatist structures}

The two countries in the case study have similar current targets to improve their energy efficiency: Germany aims to improve it by $20 \%$ by 2020 (from 2008 levels) and so does New Zealand, setting the time frame to 2012 (from 2001 levels). However, despite such superficial similarity, differences between the two countries lie in the outcomes actually achieved and the policy approach, as we shall see. According to this study's hypothesis, one factor that may explain this difference is the integrated way in which corporatist structures tend to operate. In a corporatist structured country there should be institutionalised patterns in the policy making process in place (Scharpf 1977; Olson 1982; Goldthorpe 1984; Lehmbruch and Schmitter 1982; Hall and Soskice 2001). One point that makes residential home energy efficiency policies of particular interest for the case study is the broad range of involved groups, such as tenant and landlord organisations, builders and other business organisations, environmental groups, social groups and public health advocates.

Only a few studies are published that scrutinize the impact of corporatist structures on environmental policies and policy outcomes. Lyle Scruggs examines the relationship between national political and economic institutions and environmental performance and finds that neo-corporatist countries experience better environmental outcomes than more pluralist states (Scruggs 1999). He finds evidence that neo-corporatist institutions delivered better environmental performance during the 1970s and 1980s. Scruggs suggests that the encompassing form of traditional corporatist groups, labour unions and employers, are more aware of potential negative externalities of policy decisions, because they will affect their own constituents Accordingly unions and employers are likely to support policies that are beneficial for the environment (Scruggs 1999; 2001). That contradicts the point that the representation of interests in corporatist societies is orchestrated by the most 
powerful interest groups, in particular unions and employers, who settle their conflicts at the expense of less organized groups, such as environmental groups (Heinze 1981; Offe and Keane 1984).

Corporatist arrangements marginalise interests that are not sufficiently represented, according to that argument. With the emerging environmental movement and an increasing political attention in the late 1970s and in particular in the 1980s these issues were increasingly incorporated by major interest organisations (Jahn 1998). The take-up of issues by large encompassing groups fosters the governability of these issues, in this case environmental issues (Lehmbruch and Schmitter 1982). In addition a number of authors claim that environmental issues are earlier identified and policies are earlier implemented where corporatist policy settings are present and some even consider corporatism a crucial variable for good environmental performance (Crepaz 1995; Scruggs 2001; Jänicke 1992; Enloe 1975; Vogel 1986; Jordan 2005). Others make the assumption that corporatist states are slower in adapting new policies but when they do they are more effective in implementing them and achieve better outcomes than more pluralist countries (Lundqvist 1980; Vogel 2003).

\section{Centre-left and green party strength}

Several authors suggest that the strength of centre-left and green parties has a significant impact on the effectiveness of environmental policies (Touraine et al. 1987; Klitschelt 1993). Some dismiss the hypothesis that corporatism has positive impacts on environmental performance, suggesting instead that centre-left and green party strength is the main factor that explains differing environmental outcomes (Neumayer 2003), or even suggesting that corporatism leads to negative environmental performance (Benton 1997). Green parties' central if not defining political objective is environmental protection. Hence, their political representation and influence in Parliament and government is likely to beneficial for environmental policies. Centre-left 
parties are the more likely coalition partners for Green parties and also tend to be more interventionist in their policy making. Over the period examined in this thesis there should be clearly distinguishable differences over time in the strength and influence of centre-left and green parties in Germany and New Zealand and this should be correlated with the strengthening of residential insulation policies, if this factor does have an impact on policy development.

\section{The countries: New Zealand and Germany}

This thesis will compare policies of two countries that aspire to be environmental policy champions. The former Prime Minister Helen Clark, dubbed "Champion of the Earth" by the United Nations Environment Programme (UNEP 2008), and the Chancellor Angela Merkel dubbed "Hero of the Environment" by the magazine Time (Time 2007) have both aimed to take leading positions in the global combat against climate change. This thesis looks at climate change policies that aim to improve energy efficiency, in particular domestic energy efficiency improved by home insulation. It therefore looks at relevant policies at a national and supranational level and also at the outcome of these policy approaches, which includes an overview of the current energy performance in both countries and the current level of insulation installation in residential buildings.

Both New Zealand and Germany have set ambitious targets to reduce greenhouse gas emissions and to increase energy efficiency but intention and outcome are not always identical. Detail is considered below, but the overall picture is that both countries started with energy efficiency regulations for domestic buildings by 1978 but while Germany revised those regulations regularly, they remained nearly unchanged in New Zealand for more than two decades. 


\section{Comparability of New Zealand and Germany}

As a result of different climates and different structures of energy generation and energy consumption, Germany's and New Zealand's performance in energy efficiency in the residential sector are not easy to compare. The wide range of externalities (Gaterell and McEvoy 2005) the individual does not pay for when using heating energy inefficiently are slightly different in their importance for Germany and New Zealand: for example decreased energy security is a bigger issue for Germany than for New Zealand as German homes are heated primarily by foreign oil and gas, while New Zealand homes are heated by wood or hydro-powered electricity or in some cases by domestic coal. Costs associated with poor health as a result of poorly insulated or uninsulated buildings is a more important factor for New Zealand than for Germany, in the latter, buildings are in general heated to healthy temperatures regardless of insulation. The lack of internalisation of climate change costs is a major issue in Germany and New Zealand alike, although with increasing use of electricity for heating in New Zealand most of which is generated renewably, the externalities of home heating are larger in Germany.

\section{Research methods}

For this thesis a large number of primary sources were scrutinized, such as Bills, Acts, written and oral questions and answers in Parliament, Parliamentary select committee reports, papers, petitions and reports of committee hearings. Many of these documents are accessible online. The online archive of the German Bundestag does provide scans of the original documents for the whole time frame of this thesis. The online database of the New Zealand House of Representatives offers documents for the period from 2002 onwards. Material that was not accessible online I accessed directly in the archives of the two Parliaments. 
These political and policy documents inform the sections that deal with the question of the underlying motivations for political action on the one hand and inaction on the other, in the thirty year timeframe.

\section{Data collection}

Essential for this thesis were government papers, regulations and laws as well as reports from nongovernmental organisations and research institutes. For the clear distinction and therefore for the starting point of this thesis I used quantitative data on the energy performance and thermal resistance of buildings in Germany and New Zealand. The data derived largely from government sources, such as the Department for Statistics (Statistisches Bundesamt), Statistics New Zealand, and the Ministry for Transport, Building and Urban Design (Bundesministerium für Verkehr, Bau und Stadtenwicklung), Department of Building and Housing, the OECD, and the International Energy Agency, EuroStat, the European Commission, and the Parliaments, the German Bundestag, the New Zealand House of Representatives and the European Parliament, UNFCCC and others. And also a number of studies commissioned by consultancies, universities and research institutes provided a number of valuable data for this thesis, in particular the studies of the University of Otago Department of Public Health, the Building Research Association of New Zealand, Victoria University's Centre for Building Performance Research, the Fraunhofer Institute for Building physics, the German Ministry for Transport, Building and Urban Planning, provided data to allow a sound comparison.

\section{Interviews}

Interviews were intended to provide an inside view for this thesis. The views on the specifics of policy making and political perceptions from a former Senior Government Whip and Member of the New Zealand House of 
Representatives and a former Minister to the Federal Chancellor and Member of the German Bundestag were valuable contributions to this thesis. The two politicians had been Members of Parliament for 12 (Barnett) and 15 years (Bury) and were, in their roles as Whip and Minister, heavily involved in policy making and negotiations. Of particular interest for me is their experience with ensuring majorities and negotiating political compromises. Even though their statements are very valuable for this thesis, I need to acknowledge that Mr. Bury's and Mr. Barnett's comments reflect their own views, which are not necessarily representative of other MPs.

\section{Trustworthiness}

The data on residential heating energy performances in Germany and New Zealand derive from case studies based on examinations of 400 (HEEP) to about 1400 and 1200 dwellings (Howden-Chapman 2007 and BMVBS 2008). The findings of such studies are generally recognised as being representative and are used by governments as a basis for policies on residential home insulation are built. A number of additional studies, in particular from the International Energy Agency, are based on sound data and complete the picture of the development of energy intensity and efficiency over time in Germany and New Zealand.

Information and data on the policy making processes in the two countries are based on transcripts from select committee and plenum sessions, provided by the archives in Wellington and Berlin. It needs to be emphasised that political statements in particular from a debate in the plenum of parliament do not necessarily give the best picture of positions of that time, as they are sometimes simplified, exaggerated or whitewashed. However in combination with the actual policies and their outcomes, and experiences from politicians, they give a relatively clear picture of the different positions and the driving forces behind them. 


\section{Ethical Issues}

Victoria University's Human Ethics Committee granted approval for interviews for this thesis on the $30^{\text {th }}$ of August 2008. Interviewees were informed about the topic and approach of the thesis. They were also advised about the process of how and for how long notes from the interview would be stored, and how the information from the interview would be used. A declaration from each of the interviewees and a copy of the information sheet handed out to the interviewees are attached (Appendix 1).

\section{Structure of the thesis}

In the Introduction, the preliminary evidence base of the differing policy outcomes has been explored. This present chapter has described the main elements of the hypothesis, methodology and conceptual framework. Chapter II looks at the dates when first regulations on energy efficiency in residential buildings were introduced, how these policies were designed, how often and how they were revised and how many houses were built during that time frame. For the existing housing stock, energy performance regulations as well as investment and support schemes for efficiency improvements are scrutinized. This gives a set of data that allows a comparison of the effectiveness of energy efficiency policies in Germany and New Zealand, allows the drawing of conclusions about the reasons for the differences. Chapters III and IV are the core part of the thesis and examine the time from the 1970s oil price shocks until recent years and look at the politics and policies on residential home insulation in Germany and New Zealand, coalitions and oppositions, drivers and obstacles. Chapter V draws conclusions from the previous two chapters and compares the policy developments and the broader policy environment in the two structural settings, and brings in the policy maker's view to test qualitatively the hypothesis. The last chapter discusses limitations, uncertainties and areas for further research. 


\section{CHAPTER II: EVIDENCE BASE}

This chapter provides the factual basis of this thesis. It compares the policy outcomes, i.e. differences in the development of heating energy performance in residential buildings, from 1978 to 2008 in Germany and New Zealand, and introduces the policies that led to these different outcomes. The policies and politics are discussed in detail in the following chapters.

\section{Heating energy efficiency in residential buildings in Germany and New Zealand from 1978 to 2008}

I begin with developments in energy efficiency and intensity and in particular residential home heating energy performance in Germany and New Zealand, aiming to identify tangible differences between the two countries.

\section{Germany}

After the first decade of energy efficiency and conservation policies the outcome had already become clearly distinguishable. By 1985, twelve years after the first oil price shock, total primary energy consumption was about the same as in 1973, while the economy had grown by nearly one quarter over the same period, the number of licensed cars had increased by 8.8 million to 25.8 million, and the number of centrally heated dwellings had risen by about 3 million units to some 25 million (Schiffer 1986). Not only did the numbers increase, but cars attained larger engines and homes became larger and more comfortable. Despite this significant increase, total energy consumption practically remained constant. During the years of setting the political and policy course from the first oil price shock through the decline of the oil price in the mid 1980s, the German case shows a picture of a combination of substitution for oil and conservation of energy (Hohensee 1996). In these years $(1973-1984)$ the primary energy consumption of petroleum decreased from 208.9 million tons coal equivalent (mtce) to about $161 \mathrm{mtce}$, 
representing a decline of almost one quarter (Statistisches-Bundesamt 2006). The residential building sector played a crucial role within this development. While the consumption of petrol and diesel in the transport sector rose by $30 \%$ from 1973 to 1984 , the decline of light heating oil usage, which is mainly used for residential space heating, outweighed German vehicles' increasing demand (Röhling and Mohnfeld 1985).

The absence of a suitable substitute for petrol for transport and the considerable increase in the number of new licensed cars made the building sector one of the most important options to deliver energy efficiency improvements and to decrease dependence on OPEC oil (Schreurs 2003). The following section gives an overview of developments in the housing sector in Germany in order to identify whether energy efficiency policies in this sector have been successful or not.

\section{Heating energy performance in the German housing sector}

Space and water heating in buildings account for about $40 \%$ of all energy use in Germany (BMU 2008). This draws attention to the residential sector that accounts for more than half of such energy use (BMVBS 2008a). There are about 17.3 million residential buildings in Germany of which $73 \%$ were built before 1978 when the first energy efficiency ordinance came into force (IWU 2003). Nearly half of all buildings in Germany were built between 1949 and 1978 and fewer than $30 \%$ of all dwellings are older than 50 years, mainly due to destruction during World War II (Statistisches-Bundesamt 2006). That makes Germany's building stock relatively new. In addition many buildings in the former German Democratic Republic (GDR) have been abandoned, destroyed or rebuilt. 
Figure 2: The association between mandatory standards and building energy use in Germany

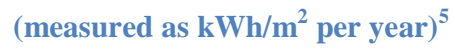

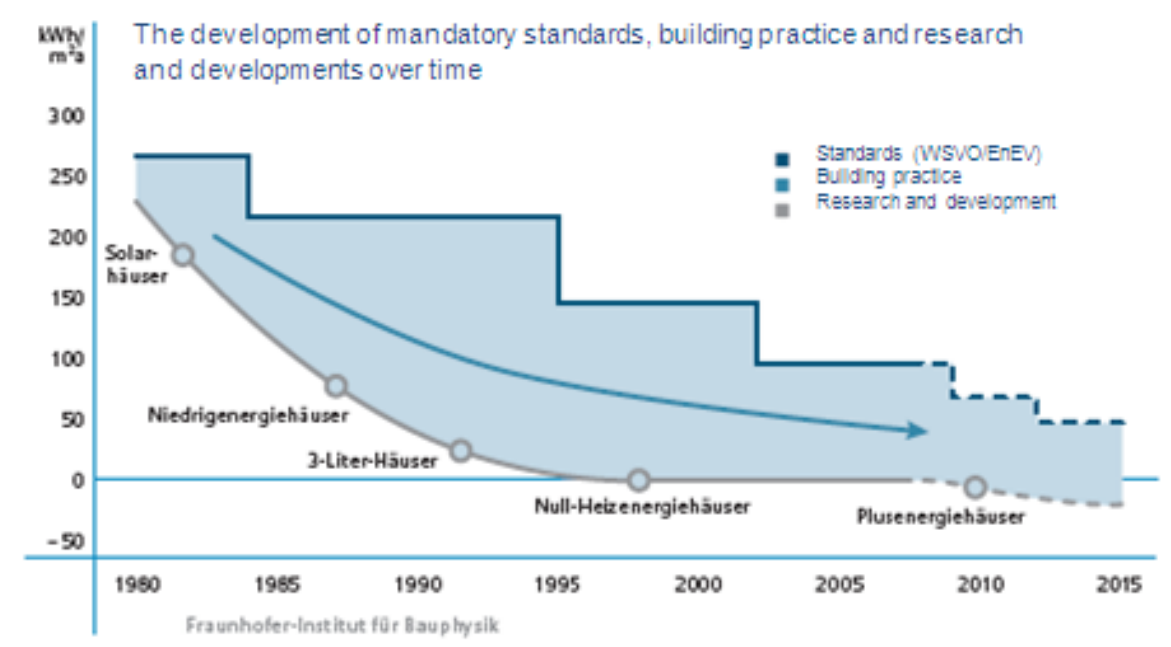

Until 1997 total energy consumption in residential buildings was still increasing, driven by a growth in living space, but since 1998 the figures show a decreasing trend. The total energy consumption in the housing sector in 2006 was on the same level as in 1990, despite a considerable living space increase of more than $10 \%$ over that period of time (Diefenbach et al. 2005). This equals an energy efficiency improvement in the residential sector of $15 \%$ from 1990 to 2005 (as reflected in the downward slope of the curve in Figure 2) and accounts for a decrease of $\mathrm{CO}_{2}$ emissions of $13 \%$ representing some 16 million tonnes $\mathrm{CO}_{2}(\mathrm{BMVBS} 2008 \mathrm{~b})$.

The effects of energy efficiency measures such as home insulation are still widely underestimated by housing owners, as the $\mathrm{CO}_{2}$ building report 2007 states (BMVBS 2008a); 38\% of those landlords and home owners in Germany who have not yet retrofitted their properties believe that this would not deliver considerable benefits. German consumers expect higher energy conservation gains through efficiency improvements in the transport sector or from more

\footnotetext{
${ }^{5}$ Solarhaeuser (solar houses), Niedrigenergiehaeuser (low-energy houses), 3-Liter Haeuser (3-liter houses), Null-Heizennergiehaueser (zero-heating energy houses), Plusenergiehaeuser (energy plus houses).
} 
efficient electrical appliances (BMVBS 2008a). The payback rate is widely underestimated and the needed investment is overestimated. The average estimate for energy efficiency related retrofits is about $40 \%$ above the actual costs (BMVBS 2008a). That delays progress in the overall renewal of the German housing stock (IWU 2003). Only about $30 \%$ of all possible energy efficiency relevant reconstruction were carried out from 1989 to 2006 (IEA 2007).

However, home insulation retrofits are increasing and the subsidy and loan schemes offered by the federal government are well subscribed (KfW 2008). Not just the number of retrofits is increasing but also the quality of insulation material that is being used is rising. Thermal insulation compound systems, which have a far better thermal performance than traditional insulation measures, were used nearly twice as much in 2006 compared to the preceding year (BMVBS 2009). However the motivation to increase domestic energy efficiency is clearly to reduce energy costs. Environmental considerations are considerably less important in the decision to retrofit (BMVBS 2008a).

The implementation of building performance policies combined with considerable government support led to a decrease in household energy consumption (IEA 2007). Some $25 \%$ of the existing housing stock has been built after energy efficiency standards, such as insulation, came into force in 1978 (Schuler et al. 2000). The rate of energy efficiency related retrofits in the existing housing stock increased from 1.6\% per year in 1994 to $2.2 \%$ in 2006 (Diefenbach et al. 2005). This adds about 230,000 state of the art energy efficient buildings to the housing stock per year. Combining these figures, more than $50 \%$ of the overall housing stock is at least at 1978 energy efficiency levels; most of them are considerably more efficient. 
From the Energy Saving Act 1976 (EnEG) and the Ordinance on Thermal Insulation from 1977 (Wärmeschutzverordnung WSVO) to the last amendment of the Energy Saving Ordinance (EnEV) in 2008, these regulations have brought down the mean heating energy for new buildings from more than $200 \mathrm{kWh} / \mathrm{m}^{2}$ per year to less than $100 \mathrm{kWh} / \mathrm{m}^{2}$ per year (BMVBS 2008a) (see Figure 2 at page 28).

German energy and climate change policies are aiming to meet a number of targets and objectives to lower greenhouse gas emissions but also to secure energy supply and to sustain the base of economic growth (BMU 2008). Even

Figure 3 Residential home heating energy consumption in Germany

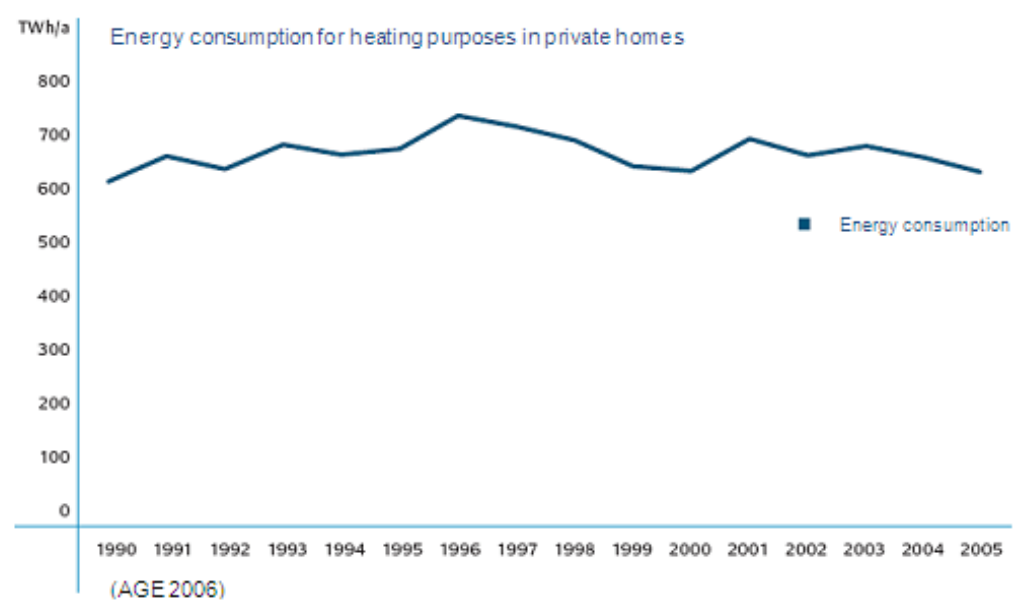

though the country is very likely to achieve its Kyoto Protocol target of a $21 \%$ reduction in greenhouse gas emissions by 2012 it remains one of the largest total $\mathrm{CO}_{2}$ emitters in the world, ranking third amongst the industrialized countries behind the US and Japan (IEA 2006). On a per capita basis Germany performs better, with 11 metric tons of $\mathrm{CO}_{2}\left(12.4 \mathrm{CO}_{2} \mathrm{eq}\right)$, lower than other developed countries, such as Australia, Canada and the US, but worse than Japan, the UK and France (UNFCCC 2009).

There is a long history of energy efficiency policies and regulations in Germany that led to a significant improvement of its overall energy intensity with an average annual improvement of $1.8 \%$ from 1990 to 2005 (IEA 2007). 
In energy intensity terms, that places Germany among leading industrialized countries, even though it is, with 0.16 tonnes of oil equivalent per USD of GDP, still slightly higher than the average for OECD Europe (0.15) (Schlegemilch 2005). However most of the current and previous energy efficiency policies in Germany can be described as an "illustration of the success of appropriate policy packages", as the International Energy Agency points out (IEA 2007).

For this thesis the focus is on policy, however it is worth mentioning that the environmental impact of German households is still greater than that of New Zealand households, as described in the following section.

\section{The carbon footprint of German households}

Private households use a considerable amount of nature's resources. Domestic buildings cover about $52 \%$ of the settlement area; households consume some $27.3 \%$ of all end-use energy and cause $22.7 \%$ of Germany's $\mathrm{CO}_{2}$ emissions (Rehdanz 2006). Greenhouse gas emissions from residential buildings are decreasing as a result of a larger share of gas and renewable energies within the energy mix but also because of considerable improvements in energy efficiency. Nonetheless energy consumption and land utilization still show an increasing trend. The determining factor for that is part of the demographic change that Germany is experiencing - in particular, the increase of living space per person in private households, as grown-up children move out, and parents stay in oversized dwellings. As a result the mean living space per person has grown 13\% over the last decade (1996-2006) (Diefenbach et al 2005). Even though energy demand per square metre fell over the same period by about $9 \%$, the overall trend in energy demand is still increasing.

Energy efficiency policies become relevant to climate change when energy generation is based on fossil fuels; it is therefore crucial to identify the sources of carbon emissions related to the housing sector, in particular for space 
heating and cooling. Electricity is only a minor source of heating in Germany, but becomes increasingly important for space cooling, which means that the generation of Germany's electricity becomes increasingly significant to the level of carbon emissions of buildings.

Primary energy demand in Germany has fallen since 1991 by $3 \%$ to approx 14210 Petajoule (PJ) in 2006, whereas electricity generation increased by about $15 \%$ to $2226 \mathrm{PJ}$ (Statistisches-Bundesamt 2006). The largest share of the electricity is generated by nuclear energy (26.3\%) followed by lignite with $25 \%$ and coal with $21.7 \%$. Renewable energies generated slightly more than $10 \%$ of Germany's electricity (BMU 2007). With coal and lignite as major sources of electricity generation, an increase in energy efficiency accounts for a considerable reduction of greenhouse gas emissions.

Of particular interest for this thesis are the sources of residential space heat. Residential buildings in Germany are predominantly heated by oil and gas which account for 31.8 and $47.7 \%$ of residential heating energy consumption respectively (UBA 2006). Another considerable number of buildings, 13.7\%, are connected to district heating networks, which are powered primarily by fossil fuels, but also increasingly by combined-heat-power, waste and biomass (Statistisches-Bundesamt 2006). Electricity, coal and wood are only used marginally as heating sources with some $4 \%, 1.3 \%$ and $1 \%$ respectively (Statistisches-Bundesamt 2006).

\section{New Zealand}

After the first oil price shock in 1973 industrialised countries started to aim for more independence from OPEC oil with a mix of policies that aimed to increase energy efficiency and to decrease energy consumption and energy intensity, and to find substitutes for oil (McKay 1975). At this time however energy consumption in New Zealand continued to grow. The two oil price shocks in 1973 and 1978 influenced the trend only slightly and for a short period. At the time, when energy prices in other western countries were surging, they remained low in New Zealand thanks to domestic energy 
resources, for example the vast Maui field, discovered in 1969 and in full production ten years later (Todd Energy 2008). The overall trend over the decade from 1974 to 1984 showed clearly an increase in energy consumption with an average rise in total energy consumption of $2 \%$ per year, which is remarkable as it appears to be the opposite to the trend seen in most other OECD countries. Also the per capita energy consumption increased in New Zealand considerably by about $13 \%$ (Lonergan and Cocklin 1990). The energy/GDP ratio in New Zealand also kept on growing over the period, while the improvements (reductions) in energy intensity in other countries took their energy/GDP ratios down. While countries such as Germany were able to decouple energy consumption from economic growth with considerable success, as seen in the declining energy/GDP ratio, the opposite happened in New Zealand, with an increase of 36\% between 1973 and 1989 (Lonergan and Cocklin 1990; MfE 1992). The extent of this increase can be largely attributed to the introduction of a few energy intensive industries such as aluminium and steel manufacturing and also to growth in the transport sector. This energy intensity growth is seen as representative of the failure of New Zealand governments to promote and support energy efficiency effectively and on a consistent basis (Bührs and Bartlett 1993). Decoupling of energy consumption from economic growth can be considered one of the major indicators for improvements in energy efficiency. Energy efficiency policy, such as it was, largely failed in New Zealand. The light handed energy policies, inspired by the belief that the market would be able to drive efficiency gains on its own, are an example of the prevailing liberal market ideology dominating NZ's energy and environmental policies over the 1980s and 1990s, as described later chapter IV(Wilson/Horrocks 2008).

The International Energy Agency, in which New Zealand sought membership in 1974, suggested that the country's focus solely on energy supply and substitution had created "insufficient outcomes" (IEA 1984) compared to other OECD countries. The agency came to this conclusion after examining New Zealand's energy conservation policies, found to be among the weakest of any developed country (IEA 1984). Even the Ministry of Energy of that 
time itself admitted that "energy conservation policies have lacked consistent goals or programmes" (Lonergan and Cocklin 1990).

\section{Heating energy performance in the New Zealand housing sector}

Even though the energy sector itself was by and large under control of the national government during the 1970s there was virtually no consideration of conservation measures during that time and the decentralization of energy planning later on rendered this aim increasingly difficult. The domestic sector was targeted mostly with passive programmes, such as consumer education and information offers by bodies such as the energy advisory board. Energy conservation loan schemes were only offered for the industrial and commercial sector and education schemes ended often already during their planning phase. Only the revision of the New Zealand building code and the introduction of mandatory insulation installations can be described as a regulatory policy approach in this field. However the domestic sector in fact consumed more energy per dollar in 1984 than in 1974 (Lonergan and Cocklin 1990).

Within the domestic sector coal was considerably replaced by electricity as a heating source. This substitution of coal by electricity would have been favourable for the greenhouse-gas balance but as the increasing electricity demand was matched by fossil fuel combustion rather than a further use of hydro power or other renewable energies, the actual gain from this switch is negligible from a climate change perspective. Furthermore the overall energy consumption of the domestic sector continued to rise, which leaves this sector with an increasing carbon footprint, despite any political efforts to make energy conservation, and implicitly also emissions, the main target of New Zealand's energy policies.

The increasing electricity demand from the domestic sector has largely been met with coal, which in New Zealand has been converted to electricity at an efficiency of $26 \%$ in 1985 (Odum 1981). Taking that into account the lack of 
efficiency improvement was even more striking than stated above. Energy consumption per capita has risen nearly a quarter (24\%) and the total energy consumption about 27\% since 1974 (Patterson 1983). This differs sharply from the situation in most other developed countries. When the oil prices started to decline significantly in the early 1980s most developed countries had working energy efficiency improvement mechanisms already in place, unlike New Zealand. The increase of energy-intensity of the household, transport and manufacturing sectors can probably be attributed to the slowdown of the economy and the following fall in output and capacity utilisation in many businesses (IEA 2001). After the economy started to recover in 1991, energy intensities started to decrease in most sectors as companies gained the ability to invest in more energy efficient equipment. Space heating, however shows an increasing trend, which is expected to continue as energy use for heating purposes is amongst the lowest in the OECD and levels of indoor heating and comfort are rising (IEA 1999). While other residential energy consumptions are close to the OECD average, energy consumption for space heating is very low but is considerably increasing (IEA 2006). This increase could be at least partially offset by retrofit insulation of existing buildings and higher standards for new dwellings. The minimalist use of interventionist policies and the reliance on informing and encouraging policies are likely to prevent insulation from contributing significantly to energy conservation (IEA 2001, 2006).

With rising energy prices, energy insecurity and climate change concerns, the New Zealand government is increasingly focusing on energy efficiency. In 2001 a target for energy efficiency improvements of $20 \%$ by 2012 was set was set by the government. However there has only been a minor improvement of about $1.1 \%$ by 2006 (IEA 2006). For many years energy efficiency awareness has been low amongst New Zealanders partially because of low energy prices 
compared to other OECD countries, including Germany ${ }^{6}$ (IEA 2006, IEA 2007) but also as a result of the relatively benign climate and rather unique behaviour patterns amongst New Zealanders such as " stoic resignation to cold“" (Baines et al. 2006). The overall thermal performance of the building stock is comparatively poor, which provides a considerable potential for the country to improve energy efficiency (IEA 2006).

Some studies suggest that insulation standards for basic measures such as ceiling and under-floor insulation have only a limited impact in lowering electricity consumption (French et al. 2007; Isaacs et al. 2006).

The difference including all heating sources is significant with $3,180 \mathrm{kWh}$ used in an un-insulated house per year compared to $2,410 \mathrm{kWh} /$ year used in an insulated house (Isaacs et al. 2006). The overall energy efficiency gain from insulation measures (basic insulation of ceiling and under floor) is estimated for households where a household member had a respiratory problem at around 20\% (Howden-Chapman et al. 2005). Although respiratory problems are widespread in New Zealand, the energy saving from installing insulation in a house where there is not a household member with a respiratory problem is difficult to estimate, as it will depend on the extent to which the gain is 'taken back' as greater comfort (discussed later) and the extent to which the household takes the gain as a saving on its energy bill.

Looking at houses as a potential means to improve the carbon footprint, insulation becomes useful to the extent that additional heating sources apart from electricity are gas and coal, and therefore sources of $\mathrm{CO}_{2}$ emissions. Insulation does lead to are warmer and dryer houses that provide a significantly healthier indoor environment for its occupants (HowdenChapman et al. 2005). Due to the take-back or comfort effect, insulation does not always lower energy consumption simultaneously, as a higher space heating effort may become worthwhile (Howden-Chapman et al. 2009).

\footnotetext{
${ }^{6}$ New Zealand domestic electricity prices averaged, in 2006, 0.138 USD per kWh in 2006 and Germany with 0.212 USD per Kilowatt-hour (IEA 2006, IEA 2007)
} 
About 900,000 New Zealand homes were built before 1978 when basic insulation measures became mandatory (IEA 2006). At least one third of these houses have inadequate or no ceiling insulation and more than one million New Zealand houses have no under-floor and little or no wall insulation, together representing more than 66\% of the housing stock (French et al. 2007; IEA 2006). Thus there remains huge potential to improve energy efficiency and reduce emissions from residential energy use.

The introduction of insulation standards in New Zealand in 1978 followed a political development that occurred almost everywhere. Interestingly these standards remained nearly unchanged for almost three decades, with slight adjustments in the meantime. The question is, then, why did New Zealand not raise its insulation standards for such a long time?

The "rolling back the state" mood (discussed in chapter IV) among both some of the Governments over this period and among a wider public is one part of the answer but there are more factors that contribute to the procrastination on this issue. First of all, residential energy use per capita is amongst the lowest in the OECD (IEA 2001), and this is because of the low use of energy for space heating. The magnitudes of other residential energy uses are much closer to the average in developed countries. New Zealand's mild climate results in only $50 \%$ of the average number of heating degree-days compared with central Europe and only modest cooling demand in summer (IEA 1999), which can be identified as one reason for the holding back of initiatives to increase insulation standards. However there is strong evidence from a number of studies on health inequality of New Zealand houses, that there is indeed a significant lack of insulation that has to be improved (HowdenChapman et al. 2005; French et al. 2007; Howden-Chapman et al. 2007; Isaacs et al. 2006).

During the late 1980s and early 1990s the growth in living standards stalled in New Zealand, which resulted in low levels of investment in house retrofits. While economic growth started to increase in the early to mid-1990s so did energy demand for residential space heating, even though the increase was 
small enough to be outweighed by efficiency gains, that even led to a $1.4 \%$ decrease in energy intensity of the residential sector over 1974-1984 (IEA 1984). A large unmatched efficiency potential would occur, if New Zealanders start to heat their houses to temperatures typical for developed countries, as suggested by public health advocates. But this trend is still very weak, which is one reason for the slow process of increasing insulation standards.

The total energy consumption in the New Zealand residential building sector increased from 1975 to 1998 by approximately 30\%, or $1.2 \%$ annually (EECA 2001). To add some more facts to this figure, during the years between 1981 and 1990 New Zealand's population increased by $6.2 \%$ and the number of houses increased by $7.4 \%$. Over the same time, total energy use in residential buildings increased by 20\% (EECA 2001). In 2001 an annual increase of around 1.7\% was projected for the years up until 2020 (EECA 2008). By 2001 around $70 \%$ of dwellings did not meet the New Zealand home insulation standard, which is considered to be lower than most overseas standards (EECA 2001). In summary, the majority of New Zealand's residential buildings are not insulated, or not appropriately insulated, with the consequence that substantial energy is being wasted, a significant part of which is high grade energy, namely electricity.

\section{The carbon footprint of New Zealand households}

The residential sector accounts for about $12 \%$ of New Zealand's total delivered energy use, representing NZ\$ 1.1 billion spent by households for space and water heating and appliance operation. Even though the country's per capita greenhouse gas emissions are among the highest in the world, ranking $11^{\text {th }}$ as a result of a large emission-intensive agricultural sector, New Zealand households' energy consumption creates only part of this footprint with 0.38 tonnes $\mathrm{CO}_{2}$ per household per year, compared to $3.11 \mathrm{tCO}_{2}$ per household in Germany (Enerdata 2006). The main factor influencing this is 
the significant share of renewable energies in New Zealand's electricity generation mix with two-thirds of electricity production being from renewables (MED 2007). Only two other OECD countries, Norway and Iceland, generate more power from renewable sources (IEA 2008b). Another factor in New Zealand is that wood consumption for home heating is comparatively high and largely carbon neutral. Nevertheless, it may be noted that if household energy consumption for heating does rise with rising incomes over time, it is likely that much of this increased demand could be met from gas and coal-fired power generation, which has a higher carbon footprint than the average unit of electricity currently generated in New Zealand.

\section{Thirty years of energy consumption in Germany and New Zealand}

Even though the overall number are hard to compare due to the different ways of measuring residential home heating energy performance the trends give a clear indication of a different development in Germany and New Zealand. Energy intensity in Germany decreased by 25\% between 1974 and 1984 and also energy consumption for space heating $\left(\mathrm{kwh} / \mathrm{m}^{2}\right)$ decreased by about $50 \%$ from 1974 to 2000. A contrasting development occurred in New Zealand, overall energy intensity increased by 36\% between 1973 and 1989 and so did the energy consumption for space heating from 1975 to 1998 , by about $30 \%$. Figure 4 shows the development of $\mathrm{CO} 2$ emissions per kWh of electricity and heat output in the two countries over the last forty years. It shows a significant difference of the level of emissions, with Germany emitting about 900 gram CO2 more per $\mathrm{kWh} /$ heat unit in 1960. That indicates the high level of environmental pressures in Germany deriving from the production of electricity and heat and the relatively low pressures in New Zealand, which remained comparatively low until recently. 


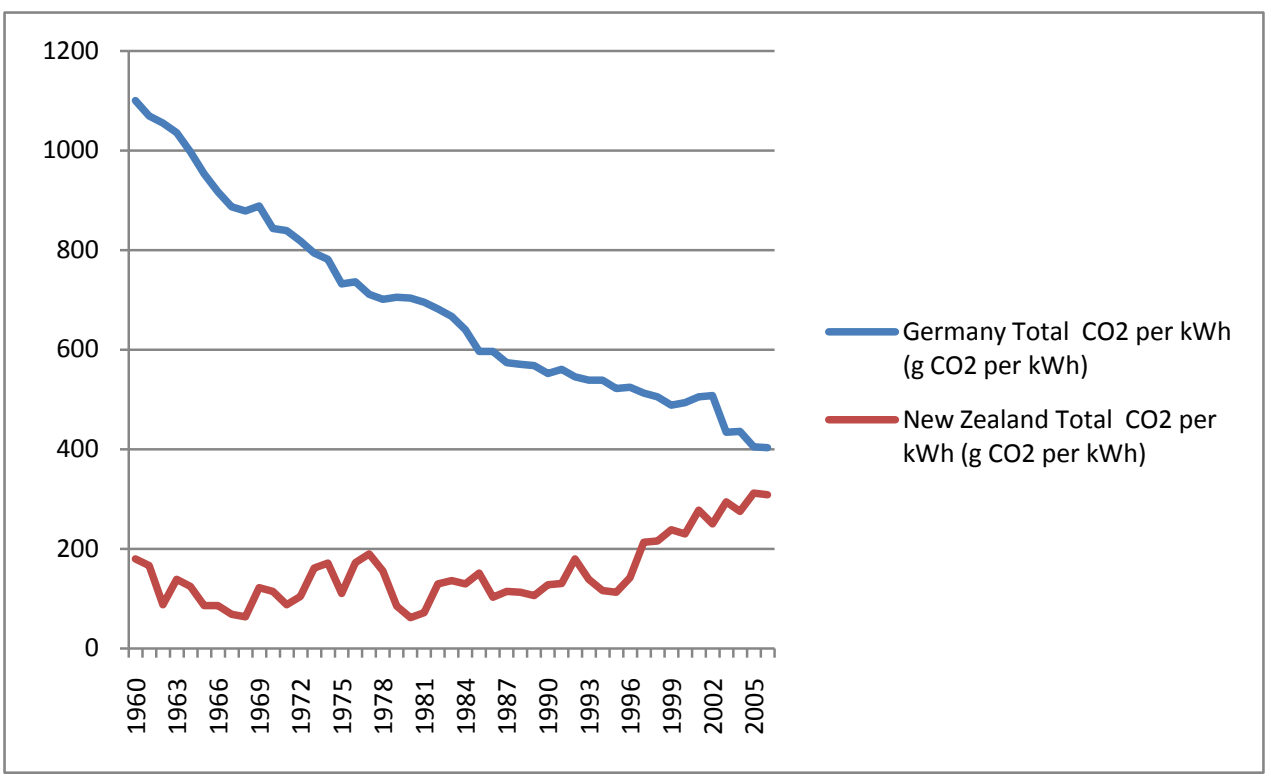

Figure $4 \mathrm{CO}_{2}$ Emissions per $\mathrm{kWh}$ of electricity and heat output (Source IEA 2009)

Figure 4 also shows very different trends, with emissions in Germany decreasing significantly and rising in New Zealand, even though they are still below the German levels. It shows that, while Germany managed to decouple economic growth from energy consumption to a certain extent, New Zealand did not achieve much improvement in this area. That resulted in decreasing greenhouse gas emissions in Germany and increasing emissions in New Zealand over the last thirty years.

\section{Thirty years of policies in Germany and New Zealand}

The compelling difference in policy outcomes between Germany and New Zealand is based on different sets of policies in the two countries over the thirty years. While in Germany insulation standards and obligations were constantly improved and remained on the political radar, there was a large gap in policy in New Zealand after the first introduction of insulation standards. Chapters III and IV will explore the thirty years of policy making to identify the reasons for these two different developments. 
Table 1 Residential home insulation policies and supporting measures in Germany and New Zealand 1978-2008

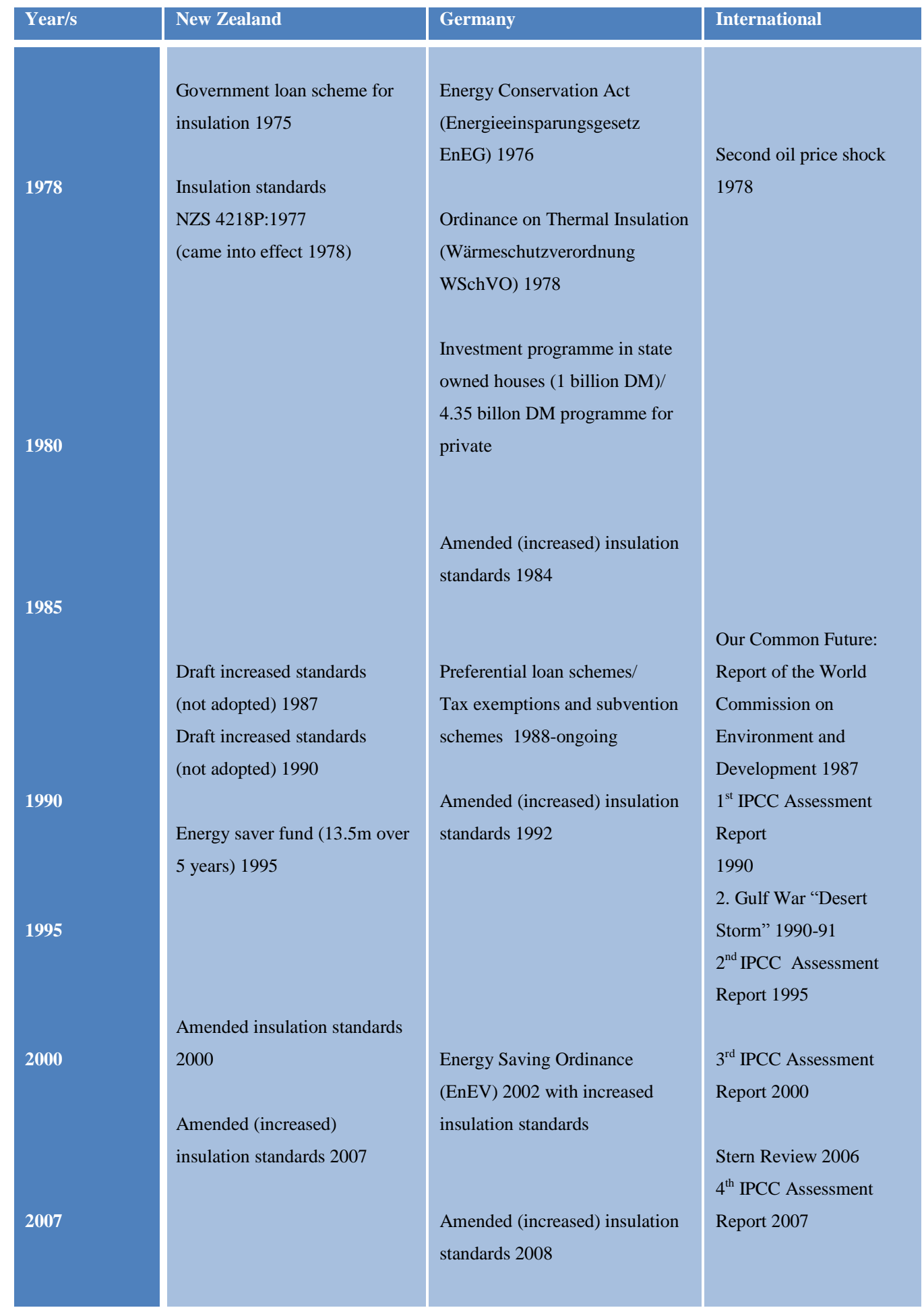




\section{CHAPTER III: RESIDENTIAL HOME INSULATION POLICIES IN GERMANY}

This and the following chapter are intended to build the basis to test institutional differences and their influence on policies and policy outcomes. It will start with the two 1970s oil price shocks and its influence on government policies, politics and individuals. The first part of this chapter includes sections on the debate in government and parliament and the influence of different factors. It deals with questions around the motivation for policy change, the size and significance of drivers that fostered policy intervention, and takes a deeper look on the background of the policy developments and how coalitions emerge.

\section{Coalitions and oppositions: how policies emerged}

Following the oil price shock in 1973/1974 the government of the Federal Republic of Germany started focusing on energy issues, and in particular on residential energy efficiency, with the introduction of thermal insulation standards and regular revisions of the building code. The German industry was able to decouple to a considerable degree energy consumption and economic growth even before the first oil price shock (Bertelsmann 2009a). This was driven by cost-benefit analysis rather than regulation (Hansen 1990). Thus, the building sector became a cornerstone of German energy conservation policy strategies (Thomsen et al. 2008). In the early 1970s the German Energy Conservation Act (Energieeinsparungsgesetz EnEG), created the legislative basis of regulatory measures such as the Thermal Insulation Ordinance (Wärmeschutzverordnung WSchVO) that came into effect in 1978 and set first minimum standards for new buildings.

These first milestones on residential home energy efficiency were not always undisputed. Minor issues such as insufficient air circulation caused by too airtight windows were debated in parliament (Sperling 1983). Also, some raised questions about whether certain energy efficiency measures were used too 
ambitiously (Gerstein 1980). Despite minor, rather technical, tensions the general trend towards more efficient buildings was rarely disputed (Röhling and Mohnfeld 1985). The government invested significantly in energy efficiency schemes. For example the federal government invested about 1 billion DM ( 1bn NZD) in the first seven years for windows with higher thermal resistance for federally owned buildings. Further 4.35 billon DM were offered to private home owners and local councils, a major owner of rental properties, for insulation purposes during the first five years of the new building code (Sperling 1983).

In terms of the individual's role in energy conservation the significance of energy prices as steering tool was clearly identified and used. But the conservative-liberal government made also clear that efficiency standards that were too tough and energy prices that were too high would endanger the broad and voluntary consensus amongst people about the need for energy conservation (Bangemann 1984). The promotion scheme, initiated be the SPD-led government, mentioned earlier, was not extended by the succeeding CDU/CSU-led government after it expired in 1983, for budget reasons (Jahn 1985) and also because further government support was not considered necessary (Echternach 1987). The 4.35 billion DM investment programme was seen as an initial start to attract private investment of up to ten times the government investment (Jahn 1985). Furthermore, increasing energy costs would make government support unnecessary as investments become cost effective (Bangemann 1984). When the government introduced higher insulation standards in 1982 (which came into effect in 1984), it took an annual price increase of five percent for light heating oil into its considerations about cost effectiveness (Jahn 1985). However the price level of light heating oil in the mid 1980s stabilised and remained relatively constant for about three consecutive years, that raised questions about cost effectiveness of insulation measures and also about the need to increase insulation standards further (Sperling 1985). 


\section{Influences and drivers}

Shift in policy objectives from energy security to environmental protection

The primary objective of energy policies in the late 1970s and early 1980s was to become less dependent on oil imports from the OPEC countries, but during the mid-1980s the focus shifted also towards sustainability and environmental protection. This was accompanied by the establishment of the Ministry for the Environment in 1986. Until 1984, when the first amendment of the Thermal Insulation Ordinance was passed, the price of oil was the principal driver behind the political decision, but in 1995, by the time the regulation was updated for the second time, environmental and climate protection were driving the agenda (Schmidt 2007). Prior to the second amendment, the parliamentary commission on "Protection of the Atmosphere" identified and emphasized the enormous energy saving potential of building renovation (Bundestag 1992). It started in the early 1990s when Germany started to strive for a reputation as a global pioneer in environmental policy. As an offshoot of the anti-war movement and boosted by the Chernobyl disaster, a strong environmental movement formed in the 1980s that led to the foundation of the Green Party. Thus, environmental issues were increasingly addressed by all parties in order to cope with the changing political environment. The country's plan to reduce greenhouse gas emissions, presented to the 1992 Rio Convention included some of the most ambitious objectives internationally (IEA 2007).

In 1991, the year of the Second Gulf War, attention increased again to the potential of energy efficiency and an amendment for increased insulation standards was drafted (Loewenich 1991). But this draft did not only address the increasing instability of Germany's energy security it considered climate change and environmental degradation not only as being equal to energy security but it even made them the primary target of that policy. That can be seen as an answer of the CDU/CSU-led government to the growing environmental movement and the Green party but it also can be argued that 
conservative and green politicians have a lot in common and share a large number of values (Sontheimer 1983). Early evidence for that claim is the initiative from the CDU governed Land Baden-Wuerttemberg ${ }^{7}$ in 1989 to amend the insulation and heating performance standards as a way to mitigate the anthropogenic climate change (Baden-Wuerttemberg 1989). From this point on energy efficiency policies have had a very close relationship to climate change mitigation issues and also, climate change policies were not attributable to either side of the political spectrum per se. Energy efficiency policies echoed usually wide support from all parties in parliament. Although the design and the intensity of each energy efficiency program was debated, the overall consensus about this kind of policies was rarely disputed (Feldkamp 2005).

When socialdemocrats formed a coalition with the Green party (B'90/Die Grünen) in 1998 they made the promotion of renewable energies a highpriority policy focus, but the political aim to phase out nuclear power and to reduce the use of fossil fuels, made further improvements in energy efficiency necessary. Chancellor Gerhard Schröder's government merged regulations on insulation and heating performance to one Energy Saving Ordinance (EnEV) in 2002 and amended it further two years later.

Residential building energy efficiency remained a policy topic after the change of government in 2005. The coalition of Christian Democrats (CDU/CSU) and Social Democrats (SPD) set a number of targets and measures to improve the national energy efficiency in their coalition agreement. For example, the "Grand Coalition" increased funding for the $\mathrm{CO}_{2}$ building retrofit program to at least 1.5 billion Euros per year. The government also introduced a mandatory energy passport for buildings by 2008 and a target of energy efficiency improvements of at least $5 \%$ of the pre1978 buildings per year (CDU/CSU and SPD 2005). In addition to the 2008

\footnotetext{
${ }^{7}$ Some of the most ambitious and advanced energy efficiency projects are currently located in Baden-Wuerttemberg. The first "Passive-House" was built in the south-western state, which in 2008 is still headed by a conservative-liberal CDU-FDP government.
} 
amendments, standards will increase every five years to be able to update standards according to the progress in technology.

\section{Germany in the European context}

With the Action Plan of the Community for Energy Efficiency (European Council 1977) the issue of residential energy efficiency became a European issue, which added an additional level of governance, administration and control to this policy set but it also added an element of competition in the political and the policy process (Schlegemich 2005). Not only were European officials administering and controlling Germany's progress in energy efficiency, the European aspect was challenging Germany's reputation as home of some of the best engineers, being in the forefront of technological developments (EEB 2006).

Building energy efficiency regulations were integrated into the wider climate change policy set on a national as well as on a European level, despite decreasing oil prices in the late 1980s and early 1990s (Schmidt 2001). Germany has been strongly supportive of the ambitions at the EU level for setting common standards on energy performance in buildings. The Energy

Saving Ordinance (EnEV), and its last amendment of the $24^{\text {th }}$ of July 2007, as the implementation of the directive on the energy performance of buildings 2002/91EC, and the Energy Saving Act as its legal context, provide the technical basis for climate change relevant building regulations in Germany. The European Building Performance Directive (EBPD) led to an amendment within the context of the Energy Saving Act. However the implementation of the European directive has been a rather smooth transition into national law as German building codes exceed the EU directive's requirements for buildings (Schettler-Koehler 2007). This trend will continue as the German regulations are subject to revisions every five years and energy efficiency policies did get another boost from the EU's target to reduce greenhouse gas emissions by $20 \%$ and increase energy efficiency by $20 \%$ by 2020 (Merkel 2007). That commitment was championed in 2007 by the conservative chancellor Angela 
Merkel, one of the actions for which she was named the "Hero of the Environment" by the news magazine Time that year (Time 2007). Germany, being the EU's largest economy, has to contribute a considerable part of that target by itself. As the evidence laid out in this chapter suggests, Germany seems well positioned to achieve its policy goals, at least to a considerable degree.

The assumption that the European Union is the driving force behind Germany's energy efficiency improvements in the residential building sector, could possibly be negated by the fact that German standards consistently outpaced the European proposals and also that Germany was rather a driving force on EU level behind harmonised standards (Gullberg 2008). This was not only seen as promoting climate change policies on European level but also to give German insulation material manufacturers a competitive edge (Bury 2008). If all 27 EU member states would need to adopt high insulation standards, the demand for insulation material would significantly increase and German suppliers, with a large share in this market, could benefit from that.

\section{Policy making in Germany}

There are several features in the German residential home energy efficiency policy context that are rather typical for a corporatist country and, it is argued here, have a strong influence on policy motivations and the process. For example, the over sixty percent of Germans rent (Statistisches-Bundesamt 2006) and, therefore, constitute a large group that seeks a certain involvement and protection from the government (Bardt 2005). This contrasts to New Zealand, where $67 \%$ of the homes are owner occupied (Statistics New Zealand 2006). The German situation adds a large group to the debate about residential home energy efficiency. Tenants in Germany are well organised and represented, as described later. In addition, the structure and function of the German welfare state affects the relationship between landlord and tenant, and government and tenant. Many residential buildings in Germany are owned 
by public landlords, for example city councils, which are not only landlords but also providers of social services. It is in the interest of these landlords to provide living conditions that are healthy and affordable, as failure to do so can mean higher costs for unemployment pay (Arbeitslosengeld II) and social assistance (Sozialhilfe) that includes for example the full amount to cover heating expenses. Employed tenants who get sick because of unhealthy living conditions in un-insulated dwellings not only impose costs on the economy as a whole, through reduced productivity, but also on the government, as wage losses in cases of illness are covered by the social security system, so the government has a vital interest to improve insulation for a variety of reasons.

\section{Interest groups in the policy making process}

The German Tenant Association (Deutscher Mieterbund) is noteworthy as an encompassing and well organised lobby group that works in the interest of tenants in Germany. This organisation, along with the consumer advice centre (Verbraucherzentrale), is the central consultation partner for the issues around residential home energy efficiency (Schröder2005; Glos 2007).

The Mieterbund has a role as a partner for policy makers, but its more important work is carried out in the 350 branches of the organisation, scattered all across Germany. The tenant association acts as a mediator between tenants and landlords and it advises tenants about their rights. This role increases 'social harmony' (Schröder 2005) and ensures that issues such as insufficient home insulation are addressed in a way that satisfies both tenants and landlords. Some $97 \%$ of the disputes between tenants and landlords mediated by the Mieterbund are settled successfully (Mieterbund 2008). The association is one of the expert advisers regularly consulted by select committees in issues affecting tenants. In this consultative role it acts similarly to the consumer advice centre (Verbraucherzentrale), which also participated in the 'Energy Summits' held by the Federal Chancellor annually for the last three years. 
A central piece of legislation, which relates indirectly to residential home energy efficiency, was the introduction of an ecological tax reform. This tax reform increased energy costs with the aim of reducing energy demand. The list of experts heard during the select committee stage of the legislation in 2002 gives a good overview of the organisations that play a key role in residential building policy issues. These organisations are heavily consulted whenever relevant legislation is debated. Of particular interest are the experts heard: from the Federal association of the real estate industry (GdW), representing over 3000 major housing associations and corporations; the tenant association Mieterbund, representing almost three million members; three environmental organisations (NABU, BUND, DNR), representing together over five million members. The expert panel also included industry, unions and academics, which altogether creates a very encompassing basis on which this piece of legislation was built. The then CDU/CSU opposition argued strongly against the legislation but has not put any proposals forward to repeal the act since it entered government with the SPD in 2005. The involvement of large encompassing groups during the policy making process creates the continuity that is required for long-term investments such as insulation. This continuity is not only based on the involvement of key organisations in the policy making process but also on the integrated implementation of policies.

\section{Incorporating policies}

\section{The government}

Promotion and investment schemes play a major role in Germany's policy approach. Financial incentives have traditionally been part of the government's strategy to broaden the basis of political support from interest groups. The first regulatory measures for insulation standards in 1978 were already accompanied by investment schemes as described earlier. More than 5 
billion DM ( $\sim 5$ bn NZD) were invested in retrofits and new buildings between 1978 and 1984. Soon after these schemes expired, the federal Reconstruction Credit Institute (Kreditanstalt für Wiederaufbau, KfW) started to set up preferential loan and subsidy schemes to further improve the efficiency of the German housing stock. Those schemes have been running in Germany for more than twenty years, creating a combination of demand and support, which is typical for many policy areas in Germany. This continuity of financial support and incentives, and requirements is reflected in comparatively high standards for the energy performance of buildings.

As part of an economic stimulus package the German government is investing 1.5 billion Euros in 2009 in energy efficiency retrofits of existing buildings (KfW 2008). The current schemes "Reducing $\mathrm{CO}_{2}$ emissions from buildings", "Housing Modernization" and "Ecological Construction" provide low-interest loans and subsidies financed by the federal government. This programme provided about 80,000 low-interest loans and subsidies per year, representing some 200,000 energy efficient retrofits or newly built dwellings between 2005 and 2008 (Tiefensee 2008). Accessible financing and payback of the individual investment in a reasonable time frame create a situation that fosters the perception of energy efficiency measures as being a win-win situation (BMVBS 2009).

\section{Unions and employers}

Unions and employers are integrated into the government's climate change and energy strategies in many ways. They participate in select committee hearings, the Chancellor's 'Energy Summits' and cooperate in the development of training structures for energy relevant apprenticeships. The amended building standards are incorporated into the official training structures for building professions, which ensures that insulation material is installed correctly, in order to achieve the desired outcome. An example of this are the specified apprenticeships such as insulation specialist 
(Isolierfacharbeiter) and heat-, cool- and sound insulation specialist (Wärme-, Kälte- und Schallschutzisolierer) that deal with insulation measures and are also offered at the professional masters' level. Furthermore, it is ensured that apprentices learn the relevant standards and regulations and are sufficiently trained, usually over two to three years, to install insulation according to the approach of the relevant policy. Currently, this includes about 27 different recognised qualifications (Bundesagentur für Arbeit 2008).

\section{Interest organisations}

A number of interest organisations which participated in the policy making process are also part of the delivery on these policies. For example the consumer advice centre (Verbraucherzentrale) offers consumer information on behalf of the government, about energy efficiency, conservation measures and government funding schemes. This partnership was initiated by the Federal Ministry for Economy and Technology in 1978 and has remained active since (Glos 2007). This particular joint programme is funded by the government with 4 million Euros annually. The association of the real estate industry $(\mathrm{GdW})$, which participates regularly in policy making too, also has a role in informing its members, the landlords, about standards, regulations and funding schemes (GdW 2008).

\section{Continuity in corporatist Germany}

Beginning with the 1970s oil price shocks and with rising environmental pressures, a consensus has emerged amongst Germany's institutions about the mutually enforcing benefits of environmental and economic policies. This observation is shared by Hans Martin Bury who as Minister of State to the Federal Chancellor was tasked with 'balancing the powers' between the federal and state levels. ${ }^{8}$ He refers to the desire for political balance in

\footnotetext{
${ }^{8}$ Interviewed in September 2009
} 
Germany that is rooted in the historical experience of totalitarianism. Bury points out that in Germany: "most decisions are usually based on a political compromise based on a broad coalition" (Bury 2008). Based on support from federal government, state governments and civil society this coalition locks its partners into a process that then starts a self-reinforcing process. Decisions once agreed on remain valid even though changes in the initial rationale may occur. This ensures the level of certainty businesses and individuals need to make investment decisions that are based on medium- to long-term pay back rates. That is also reflected in, what Chancellor Angela Merkel calls, 'pacta sunt servanda' (Latin for agreements must be kept), which means that the new government will, at least in general, honour the agreements achieved by the previous government (Merkel 2005). 


\section{CHAPTER IV: RESIDENTIAL HOME INSULATION POLICIES IN NEW ZEALAND}

This chapter sketches the politics and policies on residential home insulation in New Zealand in a similar way as the previous chapter on Germany, which will allow a comparison of the differences in the following chapter $\mathrm{V}$.

\section{Coalitions and oppositions: how policies emerged}

Along with other governments all over the world, the New Zealand Government introduced insulation standards as an attempt to mitigate the 1970s oil price shocks. In the Budget debate on the $21^{\text {st }}$ of July 1977 Prime Minister and Minister of Finance Robert Muldoon, pointed out: "The thermal insulation of residential homes continues to be an important part of the Government's [energy] conservation policy. The Government has decided to require minimum levels of insulation for all new residential buildings where permits are issued after 1 January 1978. The standard to be adopted initially will be that currently specified for the Government's existing home insulation scheme. Arrangements will be made to phase in over a number of years those forms of construction which cannot immediately comply with the desired insulation standard. The Government is prepared to sponsor a joint programme of research with producers of products which cannot at present comply with this standard." (Muldoon 1977) When these standards were introduced in 1978, they were already disputed and considered to be a compromise between what was thought to be in the national interest and what industry could realistically achieve (Standards Association of New Zealand 1977). As the first standard in this field, it was regarded as the benchmark from which future amendments would advance as higher levels became attainable. An initial standard was needed urgently, so there was not much scope to find the appropriate level of insulation and technical solutions; this 
would be an outcome of the research mentioned by Prime Minister Muldoon. Unfortunately these amendments failed to appear for many years. Bill Birch, the Minister of Energy in the National Government of that time sketched in 1982 the targets for New Zealand's energy policies: "During the last ten years New Zealand has experienced a major energy transformation. The Government has had to re-appraise its sources and resources of energy. Its two major goals are to promote the development of indigenous energy resources and to minimize the costs of energy supply and use" (Birch 1982). Considering that the 1980s were the time of the "Think Big" energy projects and not energy efficiency regulations or standards were made priority. The influence of the "Think Big" energy projects and New Zealand's relative wealth in fossil fuel resources, on energy efficiency policies is discussed later in this chapter but it appears that the unbalanced focus on developing New Zealand's energy sources and the exploitation of new resources outweighed any ambitions to increase efficiency standards in residential homes. In 1989 there were even rumours in the Building Industry Commission about removing insulation requirements from the Building Code (Gair 1989). Even though this did not happen, the commission's proposed New Zealand Building Code simply repeated the outdated provisions of the 1978 code and did not increase them. These provisions applied to external walls and ceiling/roof enclosures of habitable spaces in new houses and it was not intended that these requirements would apply to the glazed portions of external walls or roof enclosures, but the proposed code did not include any updates to the 1978 code (Bassett 1989). The then Minister for Energy's position on insulation standards, "that they should at least be at the level justified by climatic and economic factors" (Butcher 1989) underlines the light handed policy approach in this field in the late 1980s. The allocation of competencies and responsibility for building energy efficiency regulation can be considered as another obstacle for improvement. The then policy framework split responsibilities and allowed each council to define priorities. The Local Government Act left it to the local authorities to introduce bylaws to update insulation standards that then had to be approved by the Minister for Energy 
(Section 644 Local Government Act). Years passed and the insulation requirements, originally intended as 'interim' building standard in 1977 designed for Auckland's climate, remained unchanged (Bassett 1989). The former Minister of Energy Doug Kidd said in 1996 that upgrading the building code was a key element in the National Government's energy efficiency strategy and part of New Zealand's internationally reported response to its commitments under the Framework Convention on Climate Change. Minister Kidd told in 1997 the then Internal Affairs Minister, Peter Dunne, that he wanted the Building Regulations Act amended without delay, this however did not take place (New Zealand Herald 1997). Some years later Jack Elder, the then Minister of Internal Affairs replied to a question in the House, in relation to amending the building code to tighten home insulation standards in 1999: "Officials are considering recommendations from the Building Industry Authority and I expect to receive their report in the near future" (Elder 1999). Draft increased standards were put forward by officials in 1987 and 1990 but none of them were adopted (Isaacs et al. 2006). And despite some initiatives worth mentioning, such as adopting a target of a $20 \%$ improvement in energy efficiency by 2012, establishing the Energy Efficiency and Conservation Authority (EECA) as a statutory authority (both in 2000) and increasing funding for energy efficiency improvements, the insulation requirements of the building code remained virtually unchanged until 2007, creating a policy gap of thirty years.

\section{Influences and drivers}

\section{Rolling back the state}

Interventionist policies had become increasingly rare by the time the deregulation process started in the mid 1980s. After years of tight regulation under the Muldoon government the catch-phrase "rolling back the state" became the central theme for policies in New Zealand (Le Heron and Pawson 
1996). The National government under Robert Muldoon started some slight deregulation and liberalisation policies in its last years in office but it was the Labour Government of Prime Minister David Lange, with Minister of Finance Roger Douglas, that set in motion a somewhat radical program of deregulating many sectors of the economy, in particular manufacturing and agriculture (Holland and Boston 1990). The Fourth Labour Government, "arguably one of the most radical governments in New Zealand's history" (Cullen 2004), was elected at a point when deficits and debt were rapidly expanding and nearly $20 \%$ of all tax revenues went to service the debt, as a result of massive government regulation and subsidies, in which it seemed that "all sectors of the economy seemed to be subsidising each other" (Cullen 2004). By the time it came to revise energy efficiency standards, such as the 1978 insulation standards, the government had already adopted the deregulatory policy approach. Increased regulation for homeowners, or even new subsidy schemes to promote home insulation, would have been out of step with the general policy approach in the mid 1980s. The country moved from "one of the most highly regulated of all OECD economies" in the early 1980s (OECD 1989) to one of the most liberal market economies in the world by the 1990s (Holmes 2008). Along with most of the economy, the energy sector experienced a major transition (Kelsey 1993).

Today New Zealand still has one of the most deregulated energy markets in the world (OECD 2004). In order to cope with the challenges deriving from the oil price shocks, energy planning and policy were completely integrated and centralized in a Ministry for Energy by 1979, which coordinated exploration, supply, generation energy efficiency policies (Lonergan and Cocklin 1990). With a change in government in 1984 more market oriented approach to energy planning was adopted. Parts of the energy sector were set up as corporations with commercial objectives and a stance of limited interference in the energy market was adopted. In the beginning of this second term of the Fourth Labour Government, the Ministry of Energy was weakened substantially, which again spread the responsibility for energy issues to a number of Ministries rather than one (Holland and Boston 1990). These 
political and structural deficits hindered improvements in energy efficiency policies. This was reinforced by the low electricity prices in New Zealand, which made energy efficiency ambitions less attractive as well as less cost effective for the individual (OECD 1989).

\section{“Think Big” New Zealand's way towards more energy independence}

The focus of New Zealand's response to the 1970s oil price shocks was on intensified exploration and upstream of indigenous fossil fuel resources, an increase the electricity generation capacity and investments in large energy intense industry. This strategy of the development of large scale projects was popularly called "Thing Big". It sought to tackle the economic decline and the increasing unemployment rate as well as the shortage of foreign exchange, low productivity and inflation (Cocklin and Kelly 1992). This programme included aluminium smelters and steel mills, methanol and synthetic petrol production, pulp and paper mills, the expansion of the Marsden Point oil refinery, petrochemical production, hydroelectric power projects, and the electrification of large parts of the railway. The government invested more than $\$ 7.3$ billion in these projects that aimed to create estimated 400,000 jobs, which was "clearly unrealistic" (Holland and Boston 1990).

A clear demonstration of the supply side focus of the government of the day was a contractual commitment on Maui gas, the government agreed to. In the light of energy forecasts with a rising demand, the third Labour government (1972-1975) signed the contract that committed the government to 'take or pay' (MED 2009). For a period of over thirty years (to September 2008) the government had the obligation to accept annual quantities of gas at full contract price, whether or not they actually used the full contracted volume. As electricity prices increased over the late 1970s and early 1980s as result of the oil price shocks, electricity demand declined. Furthermore the high oil prices slowed down projected economic growth. Both factors contributed to a surplus of generation capacity by 1984 relative to the projected demand 
(Cocklin and Kelly 1992). Plans to increase electricity generation further were scrapped, but strategies had to be developed to find other uses for the gas surplus, for example as heating source for residential home heating. Against this background plans to encourage or promote energy efficiency were destined to fail. This difficult situation went on throughout the 1980s until energy prices began to increase significantly in the late 1990s.

\section{Energy prices and security}

The first oil price shock had a significant impact on energy policies in western countries and the way energy as a source of economic growth was seen. The residential home sector, considered in most OECD countries as key element for energy conservation, was considered to be less important in New Zealand. This, in addition to the double-edged sword of considerable domestic gas, oil and coal resources, gave energy efficiency and conservation a comparatively low priority (Gunn 1997). Energy security and affordability has then not been forcing New Zealand to revise home insulation standards. But what happened with the second driver, the environment? With the emerging environmental movement and an increasing level of evidence for anthropogenic climate change, energy efficiency policies became more and more environmental policies in many countries. New Zealand, the country that "gave birth" to the first environmentalist party on national level (Bührs and Bartlett 1993) and signatory party of the Kyoto Protocol, did not improve energy efficiency regulations for buildings for almost three decades. It may not have appeared to be worthwhile for energy security reasons but environmentally there was a case. So why would a "clean and green" country miss that chance?

\section{Clean and green New Zealand}

New Zealand is still widely perceived as a "clean and green" country, both domestically and internationally. The "Youngest Country on Earth" (Tourism 
New Zealand 2008) is considered to be a place of scenic beauty with an intact and diverse environment. The potential loss of this image for the tourism sector, and a couple of other sectors such as organic agriculture, was valued at close to one billion dollars (around \$938 million), which included employment and tax losses (MfE 2001). The 'clean and green' image was for many years embedded in politicians' and citizens' minds and cultivated by the mass media and the tourism industry (Bührs and Bartlett 1993). Compared with other more industrialised countries, pollution in New Zealand was often regarded as minor and officials discounted the relevance of international commentaries on pollution in New Zealand such as the OECD (OECD 1996). Some claimed the country was relatively free of air pollution, even referring to New Zealand as 'well ventilated'(Cassels 1983), in regard to its remote location in the Southern Pacific and its strong winds (Wilson/Horrocks 2008) . "New Zealand has a remarkably good atmosphere, noted for the purity of its air and the clarity of its light", the ruling National Party claimed in the early 1980s (Thompson 1982). In relation to this image the assumption could be made that New Zealand's environment is robust to damage and political or personal action to protect it would be unnecessary. The recognition of being "environmentally better-off compared to many other countries" (Bührs and Bartlett 1993) blunted the concerns expressed by other commentators and officials for many years. This complacency, and the allied lack of a precautionary approach was a defining element of government policies in the 1980s and can be seen as a contributing factor to the energy efficiency policy gap (Wilson and Horrocks 2008).

\section{The climate change debate in New Zealand}

It was a National Minister for the Environment, Simon Upton, who negotiated New Zealand's commitment under the Kyoto Protocol in 1997. The Labourled government ratified it five year later, causing some protest from National, ACT and businesses, but only a little compared with 2005 when a report from 
the Ministry for the Environment on the net greenhouse gas position calculated that New Zealand had a significant liability instead of a net credit under the Kyoto obligations. At the time the government ratified the treaty, it estimated a net benefit from about 55 million tonnes carbon dioxide equivalent saleable on the international market. New Zealand, blessed with growing forests, could sell net assigned amount units for some $\$ 825$ million (at a carbon price of $\$ 15$ a tonne). The Kyoto process was thus perceived as creating economic benefits rather than putting financial pressures on businesses and households. Until 2005, despite officials advice that New Zealand should still take action to cut emissions, the net position created a relaxed view among most ministers and the public about the obligations arising from the Protocol. The assumption, reasonable at the time, that New Zealand may be "one of the very few seller nations" (Hodgson 2004) had provided a strong argument for New Zealand's participation in the Kyoto process. The Labour-led Government had claimed that not ratifying the Protocol would mean "New Zealand setting fire to a \$200 million plus cheque per annum in terms of our being a net seller of carbon credits into the international market" (Hodgson 2002). This assumption did make the Protocol's ratification in 2002 easier, but uncertainties about this positive forecast were underplayed. National and ACT argued that New Zealand should not ratify before the country's major trading partners, in particular Australia and the United States did not either. The Climate Change Response Bill, which provides the legal framework for ratifying Kyoto, was passed on the $13^{\text {th }}$ of November 2002 by 61 votes to 56 .

Strong economic growth, low wood prices and changes in technical assumptions were stated as primary reasons for the difference from earlier estimates, the then Deputy Prime Minister Michael Cullen pointed out (Cullen 2005). Driven by international commitments and its own aspirations the government intensified its ambitions to introduce effective climate change policies but proposed policies such as the carbon tax and the animal emissions levy failed to find their way into law, due to a lack of support. 
By May 2005 the estimated Kyoto position had turned into a liability of $\$ 307$ million, increasing to over one billion dollars by early 2008 (Treasury 2008). The debate in the House that followed the release of the 2005 net position report gives a good insight into the state of climate change politics of that time. The National Party, still not convinced about the evidence and significance of anthropogenic climate change, was committed to withdraw from the Kyoto Protocol and to scrap the carbon tax, proposed by Labour. For Don Brash, the then Leader of the Opposition, it was an excellent opportunity to highlight the differences between the two major parties on this issue as instead of the promised financial benefit of the Kyoto Protocol New Zealand faces a financial liability. Brash not only attacked the government's estimates he also questioned the science of climate change and the effectiveness of climate change policies, citing Bjørn Lomborg, "the famous Danish environmentalist" (Brash 2005) who calculated that implementing the Kyoto Protocol would postpone the expected temperature rise by only six years (Lomborg 2002). From National's view the Kyoto obligations were "incredibly expensive" (Brash 2005) and would have only a very small impact on the warming of the planet. The party decided against a carbon tax and pledged to withdraw from the Kyoto Protocol in its manifesto for the 2005 election (National 2005). John Key summarises National's position on climate change in the debate about the Climate Change Response Amendment Bill in mid-2005: "The impact of the Kyoto Protocol, even if one believes in global warming — and I am somewhat suspicious of it - is that we will see billions and billions of dollars poured into fixing something that we are not even sure is a problem. Even if it is a problem, it will be delayed for about 6 years. Then it will hit the world in 2096 instead of 2102, or something like that. It will not work". However, by mid-2006 the climate change debate in Parliament moved increasingly towards a cross-party agreement about the science of anthropogenic climate change, leaving only the ACT party tailoring a stance of denial. National's sceptical rhetoric had changed by 2006: "I firmly believe in climate change and always have," John Key stated after his appointment to the National leadership (List 2006). That statement indicated an emerging 
near-consensus on the science of anthropogenic climate change in Parliament. However, no consensus was evident even by 2009 , on the policies to reduce emissions. Within the first 100 days, the new National minority Government repealed several climate change mitigation measures, such as the traditional light-bulb ban and the Electricity (Renewable Preference) Act and started a review of the Emissions Trading Scheme and related matters, which was part of the National-ACT confidence and supply agreement. While putting a hold on the Emissions Trading Scheme the National Government also stopped the household insulation scheme. The scheme was part of an agreement between the previous Labour-led Government and the Green Party in support of the ETS legislation. Over 15 years one billion dollars was planned to be invested in insulation upgrades of the existing housing stock. "National is not committed to the Labour/Greens household insulation policy because it is unfunded and impractical", said the Minister for Climate Change Issues Nick Smith, calling the scheme "reckless" (Smith 2008). However, in mid-2009 a similar scheme was announced, even though with less funding, as part of an agreement between the Greens and National (Brownlee 2009).

\section{Implementing polices}

Regulations on building energy efficiency were first applied on a nationwide level in 1978 as minimum insulation standards for new houses. For more than two decades these standards remained unchanged, with only marginal revisions in 2000. However the energy efficiency standards in the Building Code in 2007 brought considerable changes. For the first time glazing was included into the thermal performance requirements and major extensions to existing houses will also need to meet minimum efficiency standards. Government funded insulation schemes were first introduced in the 1970s but were discontinued during the mid-1980s when most subsidy schemes were reviewed. For the following years, believe in market driven energy efficiency improvements prevailed. In 1995 the National Government started to introduce incentives for insulation measures for low income households. One 
of the manifestations of a growing focus on energy efficiency policies was the revision of the residential energy efficiency clause of the New Zealand building code. Clause H1 of the New Zealand Building Code, Energy Efficiency - Third Edition ( $31^{\text {st }}$ October 2007) contains the mandatory provisions for buildings in New Zealand. It defines for example R-values for ceiling, floor and walls differentiated into three climatic zones in the country. The R-value measures the thermal resistance, while the inversely related Uvalue, used in Germany, stands for the thermal transmittance.

The Energy Efficiency and Conservation Agency (EECA) has had an EnergyWise programme since 2001 in order to provide financial assistance for low-income families to carry out a range of basic energy efficiency retrofits such as ceiling and under-floor insulation, draught stopping of doors and windows and hot water cylinder wraps. Service providers are required by EECA to gain funding for installation costs from third party sources under an average ratio of 1 to 3 of EECA to third-party funding. ${ }^{9}$ For those installations low income households may be charged by service providers up to NZ $\$ 500$. Subsidised insulation is offered to low-income families only. Homeowners who do not meet this eligibility may apply for interest free loans to cover the cost of insulation improvements, estimated by the then Minister for Building and Construction at about $\$ 3,000$ to $\$ 5,000$ (Cosgrove 2007). By the middle of 2005 about 17,000 homes have been provided with basic insulation through the program, costing the government about $\$ 19$ million. The program continues to run and is projected assist up to 100,000 pre-1978 houses with the installation of basic insulation by 2012 (EECA 2007). EECA's commitment in 2008 was to upgrade 12,500 homes per year, representing about $0.8 \%$ of the existing housing stock. The total investment for subsidised loans under the 2008 EnergyWise program is set at \$23 million and is thought to cover the upgrading of about 70,000 New Zealand homes, which represents

\footnotetext{
${ }^{9}$ Under this scheme basic insulation measures for ceiling and under-floor for an average three bedroom house for the home-owner is about $\$ 1,500-\$ 2,300$. The total cost is usually around $\$ 2,200-\$ 3,400$.
} 
an investment by EECA of $\$ 328.57$ per house (EECA 2008). The new scheme based on an agreement between National and the Greens and with an overall budget of $\$ 323$ million over four years, will offer up to $\$ 1,800$ for houses built before 2000 that require ceiling and under floor insulation or a clean heating device (Brownlee 2009).

New Zealand's insulation standards and subsidy were often promoted under the "warmer, drier, healthier homes" banner (Parker 2007; Fitzsimons 2008; EECA 2008; Brownlee 2009). That reflects the expectation that most of the benefits will contribute to an increase in personal well being (including health benefits from increased temperatures in those buildings) rather than energy conservation. Climate change mitigation and energy security played only a minor role during the drawn-out policy process towards higher insulation standards in new buildings, which made the coalition building more difficult.

\section{Lack of continuity in pluralist New Zealand}

Many policies relevant to this thesis, such as the Climate Change Response Act and the Emissions Trading Scheme were based on a small majority and often highly contested. The low level of corporatism in New Zealand does not allow the same level of buy-in that ensures political longevity, based on support inside and outside of Parliament, that countries with high levels of corporatism can provide.

The list of energy relevant agreements and acts that have been repealed after the change of Government in November 2008 is stunning, for example: the Biofuel Obligation Law was repealed, the Electricity (Renewable Preference) Repeal Bill introduced, including a Thermal Ban Repeal, the light bulb ban was ended and the Emissions Trading Scheme is under revision. A number of politicians in New Zealand are steeped in the belief that policies should not interfere in personal life or businesses activities. The Energy and Resources Minister, Gerry Brownlee said, after lifting the ban on traditional light bulbs, "This government has real concerns about telling people they have to move to 
energy efficient light bulbs by decree" (Brownlee 2008). Decisions about measures such as light bulbs or insulation are a "matter of consumer choice" (Brownlee 2008). "People just want to get on with their lives unhindered by silly rules" (Hide 2009).

Policies can change relatively quickly in New Zealand. Another example for that is the home insulation retrofit scheme has been announced as part of the 2009/2010 budget, based on a Memorandum of Understanding between the Green Party and National Party. This initiative will replace the planned Household Energy Efficiency Fund, which was part of the initial Emissions Trading Scheme policy package and a key policy in the negotiations of the Green Party with the previous Labour-led Government. 


\section{CHAPTER V: FINDINGS AND IMPLICATIONS}

This chapter will review the findings from the previous chapters, consider them against the hypothesis, identify implications, draw conclusions and discuss limitations and options for further research.

\section{Findings from the case study}

Chapter II has shown a clear difference between the development of residential heating energy performance in the two countries, which initiated the hypothesis that a number of factors influence policy making and in turn outcomes. Chapter III and IV have laid out the policy development history in Germany and New Zealand, coalitions, the drivers and obstacles, and have provided evidence with which to test the hypothesis. Over the thirty years scrutinized, the study shows that structures and policy-making processes have been different in New Zealand and Germany. In particular, the level of interaction with civil society and the need for scientific evidence to support policy changes differs. The interaction of government and parliament with peak organisations in Germany led to a general consensus comparatively quickly and turned issues such as home insulation into non-partisan policy issues. New Zealand on the other hand has some of the finest studies on the benefits residential energy efficiency that support action in this area. But these did not appear until after 2000 und meanwhile the lack of consensus stymied moving forward with increased standards. ${ }^{10}$ German policy makers dealt with a few peak organisations and by German standards demanded minimal scientific evidence for action. New Zealand policy makers did not have peak organisations able to break through the resistance of conservative politicians and policy advisers, until robust studies were available, and only when residential energy prices were rising, was there enough of a consensus to initiate policy change.

\footnotetext{
${ }^{10}$ Two drafts went out for review, but were not adopted in 1987 and in 1990 (DZ 4218P).
} 
Residential home insulation can be seen as beneficial to health and comfort and is likely to be cost effective in a short period of time compared to the lifetime of a house or a mortgage term (Geller 2005; Howden-Chapman et al. 2007; Rouni 2007). More importantly it increases energy security and decreases energy related greenhouse gas emissions. However the existing barriers make clear that is not just a 'no brainer'. Markets alone are unlikely to achieve the desired outcomes and policy measures are required (Siebert 2008). Given the deficits of the market, such as a lack of an appropriate price on carbon and capital access imperfections, energy efficiency measures would not have come so far as they have without government support and even energy efficiency measures would not be as widespread as they are, even though they are cost effective in most cases (Stern 2007). To be successful energy efficiency needs to be supported by appropriate regulation, financial incentives and political continuity (JPMorgan 2007).

Chapters III and IV have laid out New Zealand's and Germany's policy approaches in this domain. They have shown several contrary trends. Initiated by the 1970s oil price shocks and increasing attention to environmental issues, a broader coalition across the institutions of the German corporatist system emerged, forming the basis for consensus-oriented policies on climate change and energy security. A consistently high level of corporatism in Germany enabled policy development and enhanced implementation (Siaroff 1999). The bold policy moves in Germany started from a high level of pollution and energy insecurity. Based on a broad institutional network, policies were continuously updated and improved by centre-right and centre-left governments alike.

In New Zealand in 2009 there is still no clear consensus about a general policy approach to climate change. In energy policy, the focus remains largely on the energy supply side. The last years of the Labour-led Government indicate that in pluralist countries centre-left and green party strength are an important factor for the effectiveness of climate change polices. This is underlined by 
the moves towards various climate change policy measures, in particular the Emissions Trading Scheme, in 2008, and the review and amendment of this and the and repeal of other policies by the new National Government in 2009. The policy gap in New Zealand between 1978 and 2007 coincides with several issues that underpin the hypothesis. The developments in New Zealand with supply-side oriented 'Think Big' energy projects, the public and political perception of low domestic environmental pressures and an inconclusive climate change debate, kept the pressures for policy measures low and weakened the power of relevant interest groups. Relatively low energy prices until the early 2000s also weakened the pressure for improved energy efficiency. Furthermore the 'rolling back the state' approach initiated in the mid-1980s lowered New Zealand's level of corporatism further.

\section{Overcoming barriers in Germany and New Zealand}

A number of policies have been introduced by the two governments to overcome market barriers, in particular the financial barrier. Fiscal incentives, information campaigns, subsidy programmes and other policy measures have been implemented to promote energy efficiency (Linden et al. 2005; Geller 2005). These policies are offered in various forms in Germany and New Zealand. However the design of those schemes differed in the amounts offered and the requirements that have to be met.

In Germany, preferential loans are offered worth up to about $\$ 600,000$ per building with interest rates significantly lower than the regular rate. The German Reconstruction Credit Institute (Kreditanstalt für Wiederaufbau, KfW) has run preferential loan programmes for over twenty years. The current programme offers up to EUR 35,000 for new buildings and up to EUR 250,000 (about NZ\$600,000) for energy efficiency relevant refurbishment. This programme includes tax exemptions for all the investment and is coupled with direct subsidies (KfW 2008). The amount offered and the interest are directly coupled with the insulation and other energy efficiency measures: the 
more efficient the building is planned to be, the more money can be lent and the lower the interest rate (IEA 2008a).

Schemes in New Zealand tend to be less generous and have lower requirements, in terms of standards that have to be met. New Zealand's Energy Efficiency and Conservation Authority (EECA) offers subsidised loans for low to- middle-income home owners, who are earning less than NZD 100,000 p.a. (1 or 2 earners). It is offered either as an interest subsidy, up to a maximum of $\$ 1,300$; or as a grant, of 10 percent of the cost of insulation and "clean heat", up to a maximum of \$500 (EECA 2009). The difference in required standards and offered value appears consistent with the sort of policy instruments favoured by corporatist and pluralist states. However, another liberal market economy, the United Kingdom, has promotion and financing schemes in place that are very similar to the ones found in Germany. This is likely to be not only a result of pressures that are put on the UK from the European Union to achieve common targets but also a result of the environmental and resource pressures and may also be linked to the UK Labour Government's emphasis on reducing greenhouse gas emissions (IEA 2008b).

\section{Analysis of the climate for change}

Chapters III and IV have shown some significant differences in regard to the three elements of the 'climate for change'. Energy security issues as well as environmental pressures differed considerably in their intensity over the years in the two countries and the role these issues played as political motivation for policy action also differed. The structures, policy-making processes and the integration of non-governmental organisations differed, but the political constellations and the strength of centre-left and green parties was relatively similar in Germany and New Zealand over the thirty years examined. 


\section{Environmental and resource pressures}

In the 1970s when the two oil price shocks hit Germany, the country was not only dangerously exposed to foreign oil price volatility and disruptions; it was also one of Europe's worst environmental polluters (Bertelsmann 2009a). At the same time New Zealand began to tap into its fossil fuel resources and its 'clean and green' image was rarely disputed see Figure 5 (Bertelsmann 2009b).

Figure $5 \mathrm{CO}_{2}$ Emissions: $\mathrm{CO}_{2}$ emissions per capita (metric tons)

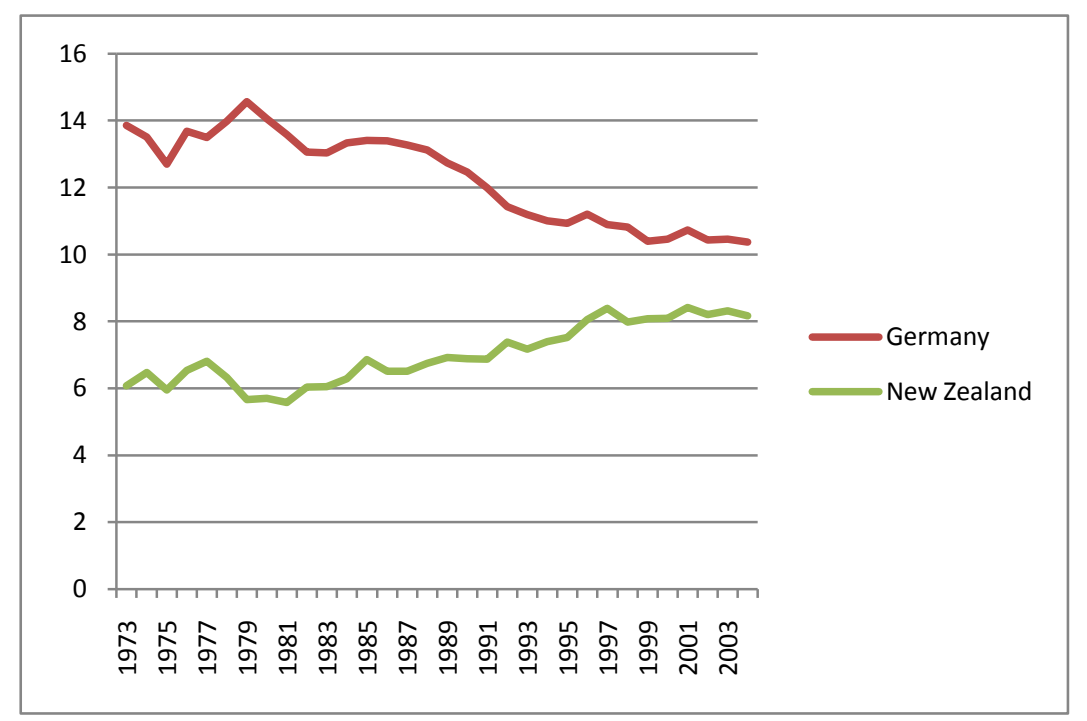

Source: WRI, IEA

These two opposing developments led to different political perceptions and priorities. One outcome of this was different energy price signals in the two countries, albeit with some similarity in overall energy price trends. The difference between Germany and New Zealand in energy price levels over the study period is notable. Low energy costs in New Zealand have often been used to explain the low level of energy efficiency (IEA 2006, OECD 2009).

Figure 6 below shows the difference in electricity costs between Germany and New Zealand and also the significant increase of electricity costs in both countries. It was not until the mid-1990s that New Zealand reached 
Germany's electricity price levels of the late 1970s. In a sense New Zealand's electricity price levels remain 5-10 years behind Germany's.

Figure 6 Electricity prices in Germany and New Zealand (Source IEA)

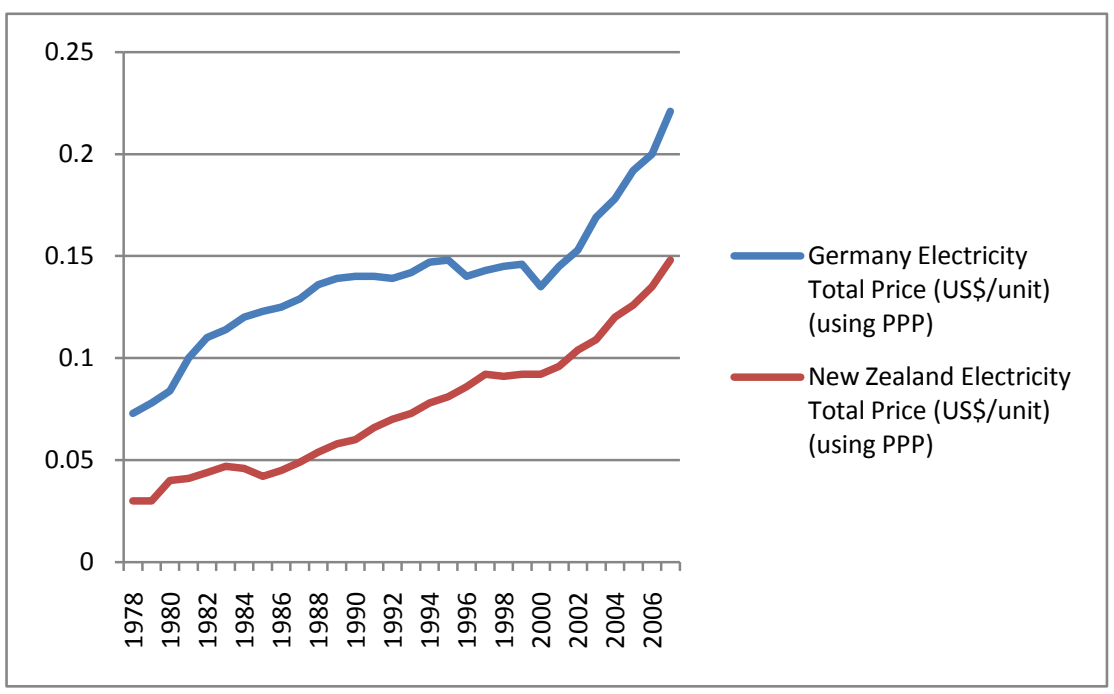

The sharply rising energy prices initiated policy action in Germany to use energy more efficiently, while the low price level discouraged similar developments in New Zealand. As the case study shows this factor did contribute considerably to policy development in Germany and later when pressures grew also in New Zealand. It does not fully explain differences in the implementation of policies, which the following factor may do.

\section{Corporatist structures}

Peak organizations do play an important role in the policy-making process. Their presence in corporatist structured countries gives policy makers the confidence they need to make decisions. Their absence in more pluralist countries leaves legislators and officials somewhat in the dark about the issues and interests that stakeholders might have (Barnett, Bury 2008).

Germany has a long tradition of an integrated policy approach, a public and business environment that is used to regulation and to a certain degree, acceptance of policy intervention. It has powerful and encompassing peak organisations that enable policy makers to engage stakeholders in a 
comparatively easy way, in building a basis for legislation and regulation (Katzenstein 1987). The German approach is also able to sustain most legislation as soon as it becomes law. Even when the government changes policy continuity is seen as an essential element to give businesses and individuals planning security. New Zealand's policy approach since the mid 1980s is characterised by a 'hands off' strategy (Holland and Boston 1990). Policy intervention has repeatedly been labelled by the political right wing as following a 'Nanny State' approach that interferes in private lives or hinders economic growth. Peak organisations in New Zealand are weaker than those in Germany. And participate in a comparatively un-coordinated, highly variable process of consultation with stakeholders.

The following Table 2 tries to identify some of these interests groups and describes briefly their different structure. The level of corporatism as a type of organised policy-making structure, enhanced by relatively homogeneous and encompassing groups, is found to be higher in Germany than in New Zealand.

Table 2

\begin{tabular}{|c|c|c|}
\hline & New Zealand & Germany \\
\hline $\begin{array}{l}\text { Environmental } \\
\text { Groups }\end{array}$ & $\begin{array}{l}\text { There are a number of different } \\
\text { organisations with a focus on the } \\
\text { environment in New Zealand. } \\
\text { Forest and Bird is New Zealand's } \\
\text { largest single organisation. And the } \\
\text { umbrella organisation ECO for } \\
\text { example has } 70 \text { member } \\
\text { organisations, ranging from large } \\
\text { organisations with a national and } \\
\text { global focus such as Greenpeace } \\
\text { Aotearoa to small organisations } \\
\text { such as Clean Streams Waiheke and } \\
\text { Friends of Golden Bay with a very } \\
\text { specific local focus. }\end{array}$ & $\begin{array}{l}\text { There are two major environmental } \\
\text { organisations in Germany, the Bund } \\
\text { für Umwelt und Naturschutz } \\
\text { Deutschland (BUND), with some } \\
400.000 \text { members and the } \\
\text { Naturschutzbund Deutschland } \\
\text { (NABU) with more than } 450.000 \\
\text { members both with a well structured } \\
\text { network on federal, state and regional } \\
\text { level and budgets of more than } 13.4 \mathrm{~m} \\
\text { Euro ( } \$ 32 \mathrm{~m} \text { ) and } 19.6 \mathrm{~m} \text { Euro ( } \$ 47 \mathrm{~m}) \text {, } \\
\text { not including the budgets of the state } \\
\text { and regional level branches. }\end{array}$ \\
\hline
\end{tabular}




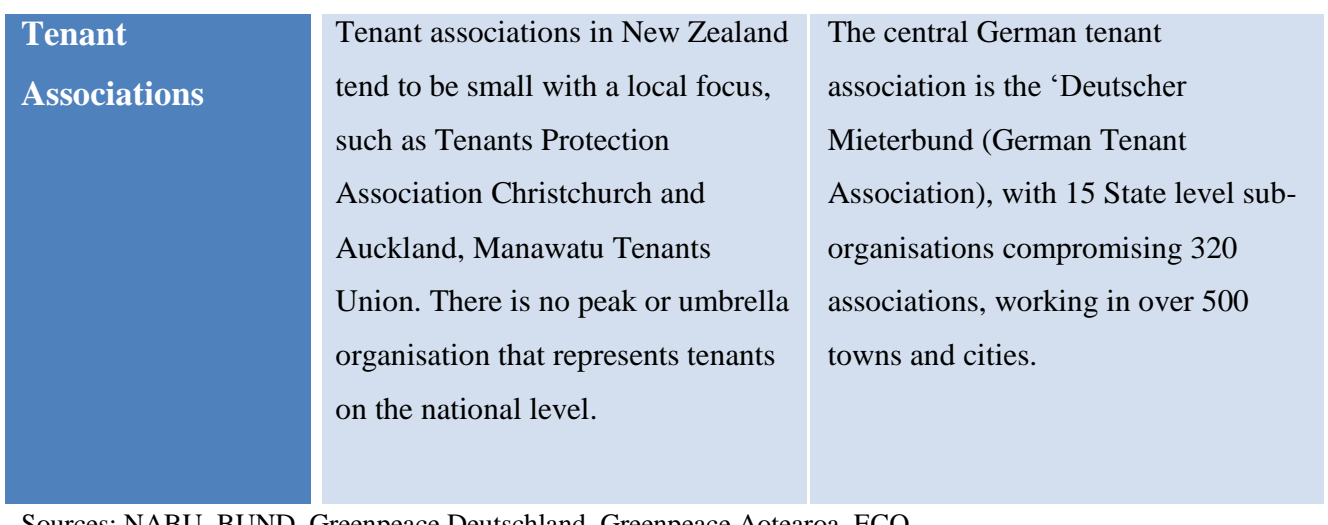

Sources: NABU, BUND, Greenpeace Deutschland, Greenpeace Aotearoa, ECO.

Legislators in Germany have a "manageable number of negotiating partners" (Bury 2008) with which to reach agreements, and they are backed by large constituencies. Consultation with the major peak organisations leaves the German Members of Parliament and Ministers with a relatively high level of certainty about the positions of relevant stakeholders, which helps to shape policies and to pave the way for successful implementation. In New Zealand however, "politicians simply don't know who to talk to", said former MP Tim Barnett, who has trained lobbyists for small interest organisations to encourage them to get involved in the policy process. According to the former Senior Government Whip, the consultation process in New Zealand does not ensure that the government is informed about the positions of relevant stakeholders, and influence policy outcomes. This is mainly because a large number of relatively small groups, in particular from the non-business side, participate in the process individually, instead of a few peak organisations that speak for them and have a mandate to bargain.

The policy makers' perception translates into tangible numbers when comparing the consultation process of the German Eco-Tax legislation and the New Zealand Emissions Trading Scheme, two pieces of legislation of similar magnitude. In Germany 45 chief executives and chair persons of the key interest organisations (unions, employers, energy industry, environment, energy consumers, tenants, landlords etc.) were heard by the members of the select committee. Each interest domain was represented by no more than three individual organisation; some were represented by only one. New Zealand's proposal of an Emissions Trading Scheme attracted 259 written submissions, 
of which 98 were presented orally to the select committee (see Table 3). Taking population disparity into account (about 20:1) German legislators would have received some 6,000 written submissions (a form of consultation that is not usual practice in Germany) and about 2,000 oral presentation would have been delivered in the German Bundestag. New Zealand's consultation practice results in a considerably higher number of submissions and presentations and also in a broader diversity of opinions articulated in them. It could be described as fragmented and individualistic. While in Germany an interest domain is represented by a very small number of representatives, who have a sufficient mandate to bargain, in New Zealand organisations and businesses represent themselves individually and if umbrella organisations are present they do not have a mandate to negotiate effectively.

Table 3 Oral presentations before a select committee

\section{New Zealand $\quad$ Germany}

\begin{tabular}{l|l|l} 
ETS (NZ) /Eco Tax (DE) & 98 & 45
\end{tabular}

Sources: German Bundestag, New Zealand House of Representatives

The German desire for political balance and a broad policy coalition stands in stark difference to New Zealand where legislation, regulations and other government schemes are often subject to change or repeal when the Government changes. Germany on the contrary is well known for its tendency to regulatory interventions that tend not to be repealed. Even though 'red tape' is also disliked in Germany, regulations and, in particular, sensible ones are at least accepted. As in other corporatist countries, Germans are used to being regulated and German legislators are used to regulating (Scruggs 2001). It is important to note that corporatist structures alone do not necessarily lead to better environmental outcomes. Until the 1970s the German corporatist structures, particularly unions and employers, resulted in more negative environmental performance. The focus of the unions was to ensure high employment rates through economic growth, often at the expense of environmental sustainability. However, when environmental and energy 
resources pressures increased, sustainability issues were incorporated and a new consensus was formed.

\section{Centre-left and green party strength}

There are a number of features that New Zealand and Germany share in terms of parliamentary culture. In both countries parliaments and governments are elected on a mixed-member proportional (MMP) system. In Germany the world's first green party members entered a national parliament in 1983. Both countries' MMP electoral systems are beneficial for small parties such as the Greens (West Germany introduced MMP in 1949; New Zealand in 1996). Both electoral cycles are comparatively short, with a three-year term in New Zealand and a four-year term in Germany (with several elections in states during the term).

The first residential home insulation standards were introduced by a conservative government in New Zealand and a social democratic-led government in Germany. In the 1980s changes occurred in government in both countries, to a Labour government in New Zealand in 1984, and to a conservative-led government in Germany in 1983.

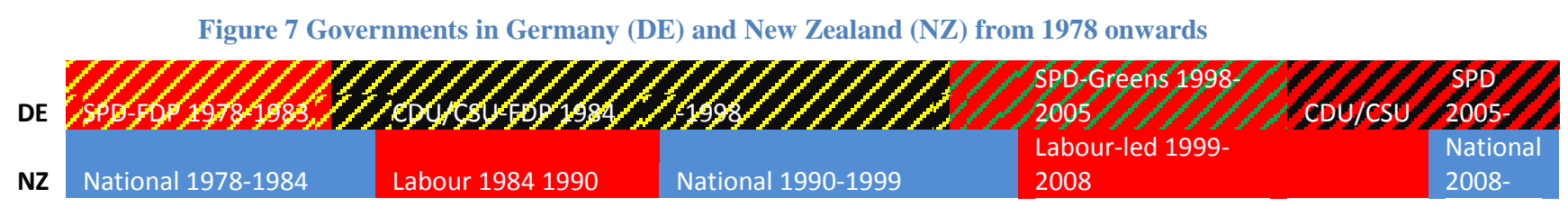

In both countries, green parties entered the political spectrum early compared to other countries. In New Zealand the first national green party in the world (the Values Party) ${ }^{11}$ was founded in 1972 although no Values party MPs were elected and the first Green party MPs were elected only in 1991. The strength

\footnotetext{
${ }^{11}$ New Zealand was the first country that "gave birth" to a green party in 1972 (Bührs and Bartlett 1993). At the Victoria University of Wellington the Values Party was launched and therewith the world's first national Green party. It took 28 years from the creation of the party foundations until the first bill, sponsored by a Green Member of Parliament, passed into law.
} 
of centre-left and green parties in both countries, measured by their representation in Parliament and government can be considered relatively similar. New Zealand had two National and two Labour (-led) governments during the timeframe between 1978 and 2008, with the Green party represented in Parliament since 1999 and the Alliance, a predecessor of the Green party, from 1991 to 1999 . Until 1982 Germany was governed by a social-liberal (SPD/FDP) coalition, which was followed by 16 years under a conservative-liberal (CDU/CSU and FDP) coalition. In 1998 a SPD-led government was formed in coalition with the Alliance '90/The Greens, which represented in the Bundestag since 1983. Thus we can note a relative balance in strength, influence and representation of centre-left and green parties in both countries, but also a significant difference in policies and policy outcomes. If centre-left and green party strength is a major factor in the 'climate for change', we should have seen similar developments in both countries. The findings of the case study, however, suggest that centre-left and green party strength influences policy developments in pluralist countries more than in corporatist countries.

The most recent home insulation policies in New Zealand were significantly driven by the strength of the Green party. First, in a political deal with the Labour Party over the Emissions Trading Scheme the Greens negotiated a home insulation funding scheme worth $\$ 1$ billion over 15 years. After the change of government in November 2008 the Home Insulation Scheme was discontinued by the National Party, but a similar scheme with $\$ 323$ million over four years (EECA 2009) was announced in June 2009 as part of an agreement between the Greens and the National minority Government. This reflects in part the emergence of a broader political coalition on these issues as we have seen in corporatist Germany, but considerably later in New Zealand. In Germany, when the SPD-led centre-left Government was replaced by the centre-right CDU/CSU-led Government in the early 1980s the new government decided initially not to extend subsidy schemes for home insulation. However, when the consensus grew about climate change and energy security issues in Germany, partisanship became increasingly less 
important for home insulation policies and subsidy schemes, and the subsidies were restored.

\section{Conclusion}

Policy development and outcomes have differed significantly in the two countries examined, as far as the evidence of the case study suggests. New Zealand introduced comparatively weak insulation standards in 1978, minor changes took place 22 years later and the next major revision followed three decades after the initial policy. The supporting policies, such as subsidised loans have been very limited and followed after years of inaction in that field. Policies in Germany on other hand were revised regularly after their initial introduction in 1978 and the supporting actions were manifold and capitalintensive.

When considering the evidence laid out in this study, one must conclude that, while resources pressures have mattered, corporatist structures have had the biggest impact on the 'climate for change'. Where these structures are not present, centre-left and green party strength can be beneficial for climate change policies, but have exerted limited influence on the pattern of policy implementation.

The initial shock of the 1970s oil crisis interacted with the corporatist structures to enhance the construction of a broad coalition, which became the basis for continuity and effective policies in Germany. In New Zealand, low energy prices and relatively low environmental pressures, as well as the lack of encompassing interest organisations weakened progress in the area examined in this thesis, which made centre-left and green party strength more important for the success of energy efficiency policies in New Zealand. When comparing the influence of each of the three identified factors for a 'climate for change', it can be noted that even though the level of environmental and resource pressures is important initially, the corporatist structure has a significant impact on the effectiveness of residential home energy efficiency policies as it enables policy makers to form a solid basis for policies, creates continuity and enhances implementation. If the level of 
corporatism is high, the strength of centre-left and green parties becomes less important for the development of energy efficiency policies and thus implementation.

Change can happen quickly in New Zealand. A Minister for the Environment was appointed in New Zealand a decade before the same happened in Germany. New Zealand was one of the first countries to adopt an environmental impact assessment system (Bührs 2002) and brought an Emissions Trading Scheme through Parliament in a few months compared to the four years in the European Union. That resembles somewhat Lundquist's picture of the hair and the tortoise (Lundquist 1980). The slow but steady moving 'tortoise' Germany outpaces the 'hare' New Zealand by its high level of continuity, which allows Germany to build coalitions that, once formed, allow policies to be adopted and implemented faster and with lower transaction costs than in New Zealand. 


\section{CHAPTER VI: DISCUSSION}

\section{How does the conclusion relate to the findings of the literature?}

As explored in the first chapter there are few studies that compare environmental outcomes in corporatist and pluralist countries on either a quantitative or qualitative basis (Crepaz 1995; Jahn 1998; Scruggs 1999, 2001; Neumayer 2003; Bernauer 2008). These studies find that either corporatism or left/green party-strength is the determining factor for lower environmental pollution. However, the interrelations between these two factors are not adequately examined in these studies. This thesis has aimed to identify drivers in the political culture and the policy-making process that indicates a difference between the countries examined, taking into account confounding factors such as energy costs and wild cards such as the emergence of scientific evidence on the question at issue in New Zealand. Even though this study is more narrowly focused and only compares two countries, the level of confidence in the findings is relatively high.

\section{Limitations}

Even though there is relatively high confidence in the results of this study the limitations deriving from examining only two countries need to be emphasised. Even though I aimed to identify structural drivers of policies, it may be that behavioural drivers for example were underestimated in this study, which in turn would decrease the importance of corporatism as a driver of change. I looked at the general development of energy intensity and at the broader debate around climate change policies, which gives me confidence that the chosen policy area is a useful and representative example of different policy developments in the two different structures. However, there was only little interaction between policy makers and interest groups for most of the time in both countries on this particular issue. Compared to other policy areas, for example the promotion of renewable energies, there were no major fights about insulation standards and supporting policies. As laid out in chapters III 
and IV, the reason for that was an early and broad consensus about insulation policies as a measure to enhance energy efficiency in Germany and the focus on supply side policies in New Zealand, to some extent itself an outcome of lower energy price levels in New Zealand. The qualitative evidence I use in this case study, the quotes from politicians and the interviews may not be representative of the range of decision makers in the two countries. Other Members of Parliament and government officials may have a different view of the interaction of interest groups with decision makers, and it is difficult to gain a comprehensive view of government officials' attitudes. Even though the evidence is based on a number of conversations with officials and Members of Parliament it is impossible to be definitive about the importance of all the factors at work in the policy domain addressed here.

\section{Future research}

To test the hypothesis additional case studies including a wider range of differently structured countries and additional policy areas would be required. Differences in the three identified factors in countries could be compared to determine which of the factors is the most influential. For future research, countries with similarities in one or two factors and significant differences in the other could be compared. For example Norway and Denmark, both corporatist countries and oil net exporters with relatively low levels of resource pressures could be compared with the United Kingdom and New Zealand, both pluralist and also having less but still significant fossil fuel wealth. When comparing these countries changes in the political coalitions would also be a very interesting component, for example comparing the change from the centre-left coalition to a centre-right coalition in 2001 in Denmark with the change of government in New Zealand. As we have seen in Chapter III in relation to German politics, the European level did have some influence in the policy making process, which may lead to the conclusion that supranational policy elements may also be considered as a factor for change, along with environmental and resource pressures, the level of corporatism and centre-left and green party strength. 


\section{BIBLIOGRAPHY}

Andersen, I., Dokka, T. 2006. Passive House Projects in Norway, Trondheim: SINTEF Building and Infrastructure Architecture and Building Technology cited. available from http://erg.ucd.ie/pep/pdf/Andersen_Dokka.pdf (accessed 12.08.2008).

Bangemann, M. 1984. Antwort der Bundesregierung, Große Anfrage MdB Burgmann und der Fraktion der Grünen, Bundestagsdrucksache 10/1380. Bonn: Deutscher Bundestag.

Barnett, T. 2008. Interview with the Senior Government Whip, 3 September 2008, consent form Appendix 1.

Bardt, H. 2005. Klimaschutz und Anpassung:Merkmale unterschiedlicher Politikstrategien, Vierteljahreshefte zur Wirtschaftsforschung, 74 (2): 259-269.

Bassett, M. 1989. Home Insulation, question to the Minister for Building and Construction, Hansard, Wellington: New Zealand House of Representatives.

Binswanger, M. 2001. Technological progress and sustainable development: what about the rebound effect? Ecological Economics, 36 (1): 119132.

Birch, W.F. 1982. New Zealand's Energy Transformation, Standards Serving New Zealand, 1932-1982: the first fifty years, Wellington: Standards Association of New Zealand.

Bernauer, T., Koubi, V., Effects of political institutions on air quality, Ecological Economics, 68 (5): 1355-1365.

Bertelsmann Foundation. 2009a. Sustainable Governance Indicators, Germany 2009, Gütersloh: Bertelsmann Foundation.

- 2009b. Sustainable Governance Indicators, New Zealand 2009, Gütersloh: Bertelsmann Foundation.

Brash, D. 2005 Urgent Debates - Greenhouse Gas Emissions-Release of Report. Wellington: New Zealand House of Representatives, cited. available from http://www.parliament.nz/enNZ/PB/Debates/Debates/f/0/0/47HansD_20050621_00000818-UrgentDebates-Greenhouse-Gas-Emissions.htm (accessed 02.07.2008).

Brookes, L. 2000. Energy efficiency fallacies revisited. Energy Policy 28 (67):355-366.

Brownlee, G. 2008. Electricity (Renewable Preference) Repeal Bill - First Reading Speech, Wellington: New Zealand Government, cited. available from http://www.beehive.govt.nz/speech/electricity+renewable+preference+ repeal+bill+-+first+reading+speech (accessed 30.05.2009). 
Brownlee, G. 2008. Light Bulb Ban Ended, Wellington: New Zealand Government, cited. available from http://www.beehive.govt.nz/release/light+bulb+ban+ended (accessed 30.05.2009).

Brownlee, G. 2009. Boost for warmer, drier, healthier Kiwi homes. Wellington: New Zealand Government, cited. available from http://www.beehive.govt.nz/release/boost+warmer+drier+healthier+ki withomes (accessed 11.07.2008).

Bührs, T., Bartlett, R.V. 1993. Environmental policy in New Zealand: the politics of clean and green?, Oxford readings in New Zealand politics, Auckland; New York: Oxford University Press.

Bundesagentur für Arbeit. 2008. Berufsinformationen, Nürnberg: Bundesagentur für Arbeit, cited. available from http://berufenet.arbeitsagentur.de/berufe/simpleSearch.do (accessed 12.08.2008).

Bury, H. M. 2008. Interview with the former Minister of State, 12 September 2008, consent form Appendix 1.

Baden-Wuerttemberg. 1989. Entwurf des Landes Baden-Wuerttemberg zur Realisierung des Energieeffizienzpotentials zur Bekämpfung des vom Menschen beeinflußten Treibhaus Effektes, 635/89, Bonn: Bundesrat.

Bundesverband deutscher Wohnungs- und Immobilienunternehmen (GdW). 2008. Finanzierung in der Wohnungs- und Immobilienwirtschaft, Berlin: GdW, cited. available from http://www.gdw.de/uploads/files/Publikationen/AH\%2050\%20Titel\% 20V orwort\%20Inhaltsverzeichnis.pdf (accessed 19.05.2008).

Burck, J., Bals, Beck, C., Rüthlein, M. 2008. Climate Change Performance Index 2008. Bonn: Germanwatch Institute.

Butcher, D. 1989. Home insulation, question to the Minister of Energy, Hansard. Wellington: New Zealand House of Representatives.

Carpenter, C. S., Stehr, M. 2008. The effects of mandatory seatbelt laws on seatbelt use, motor vehicle fatalities, and crash-related injuries among youths. Journal of Health Economics 27 (3):642-662.

CDU/CSU and SPD. 2005. Gemeinsam für Deutschland. Mit Mut und Menschlichkeit, Berlin: Press and Information Office of the Federal Government.

Chapman, R., Howden-Chapman, P., Viggers, H., O'Dea, D. and Kennedy, M. 2009. Retrofitting houses with insulation: a cost-benefit analysis of a randomized community trial, Journal of Epidemiology and Community Health (63): 271-277.

Cocklin, C., Kelly, B. 1992. Large-scale energy projects in New Zealand: Whither social impact assessment? Geoforum 23 (1):41-60. 
Cosgrove, C. 2007. New homes will now be warmer and cheaper to run, Wellington: Department of Building and Housing.

Crepaz, M. 1995. Explaining national variations of air pollution levels: Political institutions and their impact on environmental policy-making. Environmental Politics 4 (3):391 - 414.

Cullen, M. 2004. The 1st Term of the 4th Labour Government, Wellington: New Zealand Government, cited. available from http://www.beehive.govt.nz/node/19552 (accessed 10.01.2009). 2005 Urgent Debates - Greenhouse Gas Emissions-Release of Report. Wellington: New Zealand House of Representatives, cited. available from http://www.parliament.nz/enNZ/PB/Debates/Debates/f/0/0/47HansD_20050621_00000818-UrgentDebates-Greenhouse-Gas-Emissions.htm (accessed 11.07.2008).

Diefenbach, N., Hertle, H., Jahn, D., Duscha, M. 2005. Contribution of the Energy Saving Regulation and the Energy Saving Incentive Programme to the National Climate Protection Programme, Dessau: Umweltbundesamt.

Dietz, T; Ostrom, E., Stern, P. C. 2003. The Struggle to Govern the Commons, Science 302: 1977-1990.

Dyson, K., Wilks, S. 1983. Industrial crisis: a comparative study of the state and industry, New York: St. Martin's Press.

Ebel, W. Eicke-Henning, W. Feist, W. Groscurth, H-M. 1995. Einsparungen beim Heizwärmebadarf - ein Schlüßel zum Klimaproblem, Darmstadt: Institut Wohnen und Umwelt.

Echternach, J. 1987. Antwort der Bundesregierung Frage 81, Bundestagsdrucksache 11/163, Bonn: Deutscher Bundestag.

Energy Efficiency and Conservation Agency (EECA). 2007. The National Energy Efficiency and Conservation Strategy, Wellington: Energy Efficiency and Conservation Agency. . 2008. Loans scheme launched for ENERGYWISETM homes. Wellington: Energy Efficiency and Conservation Authority, cited. available from http://www.eeca.govt.nz/news/media-releases/loanschemes-launched-for-energywise-homes.html (accessed 12.08.2008).

_ 2009. Warm up New Zealand: Heat smart, Wellington: Energy Efficiency and Conservation Authority, cited. available from http://www.eeca.govt.nz/node/3107(accessed 19.02.2008).

Energy Information Administration (EIA). 2007. Electricity Prices for Households, Washington: Energy Information Administration.

Elder, J. 1999. Written Question: Home Insulation, Hansard, Wellington: New Zealand House of Representatives. 
Enerdata. 2006. World Energy Database. Grenoble: Enerdata, cited. available from

http://www.enerdata.fr/enerdatauk/publications/yearbook/world.php (accessed 22.08.2008).

Enloe, C. H. 1975. The politics of pollution in a comparative perspective: ecology and power in four nations. New York: McKay.

Federal Ministry for Environment, Conservation and Nuclear Safety (BMU). 2007. Neues Denken - neue Energie. Roadmap Energiepolitik 2020, Berlin: Federal Ministry of Transport, Building and Urban Affairs.

- 2008.Energieeffizienz in Deutschland, Berlin: Federal Ministry of Transport, Building and Urban Affairs.

Federal Ministry of Transport, Building and Urban Affairs (BMVBS). 2008a. CO2-Gebäudereport. Berlin: Federal Ministry of Transport, Building and Urban Affairs.

- 2008b. Climate Change Programme for the Buildings Sector, Berlin: Federal Ministry of Transport, Building and Urban Affairs. http://www.bmvbs.de/Bauwesen/Klimaschutz-und-Energiesparen,1533.1061353/CO2-GebaeudesanierungFoerderb.htm?global.back=/Bauwesen/-\%2c1533/Klimaschutz-undEnergiesparen.htm (accessed 12.05.2009).

- 2009. CO2 emissions from buildings. Berlin: Federal Ministry of Transport, Building and Urban Affairs. http://www.bmvbs.de/en/Building/Climate-change-and-energy-effi,1911.983325/The-programme-to-reduce-CO2-em.htm (accessed 18.07.2008)

Federal Ministry of Economic Affairs and Technology (BMWi). 2007. National Energy Efficiency Action Plan (EEAP) of the Federal Republic of Germany in accordance with the EU Directive on "energy end-use efficiency and energy services" (2006/32/EC), Berlin: Federal Ministry of Economic Affairs and Technology.

Deutscher Bundestag. 1992. Hearing commission of the 12th. 1992. First report "Protection of the atmosphere", Bundestagsdrucksache 12/2400, Bonn: Bundestag.

—. 2002. Entwurf eines Gesetzes zu dem Protokoll von Kyoto vom 11. Dezember 1997 zum Rahmenübereinkommen der Vereinten Nationen über Klimaänderungen (Kyoto-Protokoll), Bundestagsdrucksache 14/8250, Berlin: Bundestag.

Diamond, J. 2005. How Societies Choose to Fail or Succeed, New York: Viking Penguin.

European Environmental Bureau (EEB). 2006. Briefing: Directive 2002/91/EC on the Energy Performance of Buildings, Brussels: European Environmental Bureau. 
European Council. 1977. Action Plan of the Community for Energy Efficiency, R/1284/77, Brussels: European Council.

European Parliament and Council. 2002. 2002/91/EC. Directive on the energy performance of buildings Directive, Strasbourg/Brussels: Parliament and Council.

Feist, W. 2005. Heizlast in Passivhäusern, Validierung durch Messung In Forschungsberichte des Passivhaus Instituts. Darmstadt: Passivhaus Institut.

Feldkamp, M. 2005. Datenhandbuch zur Geschichte des Deutschen Bundestages 1994 bis 2003 Berlin: Deutscher Bundestag.

French, L. J., Camilleri, M. J., Isaacs, N. P., Pollard, A. R. 2007. Temperatures and heating energy in New Zealand houses from a nationally representative study-HEEP, Energy and Buildings 39 (7):770-782.

Gair, G.F. 1989. Home insulation, Hansard, Wellington: New Zealand House of Representatives.

Garrett, P. 2008. New Measures tackle spiralling Energy Consumption, Canberra: Minister for the Environment.

Gaterell, M.R., McEvoy, M.E. 2005. The impact of energy externalities on the cost effectiveness of energy efficiency measures applied to dwellings, Energy and Buildings 37 (1):1017-1027.

Geller, H., Harrington, P., Rosenfeld, A., Tanishima, S., Unander, F. 2006. Polices for increasing energy efficiency: Thirty years of experience in OECD countries. Energy Policy 34 (5):556-573.

Geller, H; Attali, S. 2005. The experience with energy efficiency policies and prgrammes in IEA acountries, Paris: International Energy Agency.

Gerstein, L. 1980. Schriftliche Fragen 158,159,160, Bundestagsdrucksache 8/3552. Bonn: Deutscher Bundestag.

Glos, M. 2007. BMWi fördert neuen Energiesparservice der Verbraucherzentralen, Berlin: Bundesminister für Wirtschaft und Technologie cited. available from http://www.bmwi.de/BMWi/Navigation/Presse/pressemitteilungen,did $=183790 . \mathrm{html}($ accessed 12.01.2009)

Goldthorpe, J. H. 1984. Order and conflict in contemporary capitalism, Joint Committee on Western Europe, Oxford; New York: Clarendon Press; Oxford University Press.

Gormley, J. 2008. Gormley Outlines Position on Plan to Introduce Minimum Energy Efficiency Standards for Light Bulbs, Dublin: Ministry for the Environment, cited. available from http://www.environ.ie/en/Environment/Atmosphere/ClimateChange/N ews/MainBody,16444,en.htm (accessed 02.12.2008). 
Greening, A., Greene, D., Difiglio, C. 2000. Energy efficiency and consumption, the rebound effect, a survey. Energy Policy 28 (6-7): $389-401$.

Gullberg, A. T. 2008. Rational lobbying and EU climate policy, International Environmental Agreements, 8 (2): 161-178.

Gunn, C. 1997. Energy efficiency vs economic efficiency? : New Zealand electricity sector reform in the context of the national energy policy objective. Energy Policy 25 (4):445-458.

Gunderson, L.H. and Holling C.S. 2002. Panarchy: Understanding Transformations in Human and Natural Systems, Chicago: Island Press.

Hardin, G. 1968. The Tragedy of the Commons, Science 162: 1243-48.

Hall, P. A., Soskice. D.W. 2001. Varieties of capitalism : the institutional foundations of comparative advantage. Oxford; New York: Oxford University Press.

Hansen, U. 1990. Delinking of energy consumption and economic growth The German experience. Energy Policy 18 (7):631-640.

Hide, R. 2009. ACT is delivering, speech to the Epsom electorate, Wellington: Hon. Rodney Hide, cited. available from http://www.beehive.govt.nz/speech/act+delivering (accessed 12.05.2009).

Heinze, R. G. 1981. Verbändepolitik und "Neokorporatismus" : zur politischen Soziologie organisierter Interessen. Opladen: Westdeutscher Verlag.

Hodgson, P. 2002. Forestry policy: answers to NZ Institute of Forestry questions, Wellington: Government of New Zealand, cited. available from http://www.beehive.govt.nz/release/forestry+policy+answers+nz+instit ute+forestry+questions (accessed 20.05.2008).

- National remain confused on Kyoto. Wellington: Government of New Zealand, cited. available from http://www.beehive.govt.nz/release/national+remain+confused+kyoto( accessed 30.05.2008).

Hohensee, J. 1996. Der erste Ölpreisschock 1973/74. Stuttgart: Franz Steiner Verlag.

Holland, M, Boston, J. (Eds.) 1990. The Fourth Labour Government: politics and policy in New Zealand. 2nd ed. Auckland: Oxford University Press. 
Holmes, K., Edwin G. J., Feulner, R. 2008. Index of Economic Freedom, Washington D.C.: Heritage Foundation/Wall Street Journal.

Houghton, J. 2004. Global Warming: The Complete Briefing, Third Edition. Cambridge: Cambridge University Press.

Howden-Chapman, P., Crane, J. Matheson, A. Viggers, H. Cunningham, M. Blakely, T. O'Dea, D. Cunningham, C. Woodward, A. Saville-Smith, K. Baker, M., Waipara, N.. 2005. Retrofitting houses with insulation to reduce health inequalities: Aims and methods of a clustered, randomised community-based trial. Social Science \& Medicine 61 (12): 2600-2610.

, Matheson, A. Crane, J. Viggers, H. Cunningham, M., Blakely, T. Cunningham, C. Woodward, A. Saville-Smith, K. O'Dea,D., Kennedy, M., Baker, M., Waipara, N., Chapman, R., Davie, G. 2007. Effect of insulating existing houses on health inequality: cluster randomised study in the community. BMJ 334 (7591): 460-471.

- - Viggers, H., Chapman, R., O’Dea, D. Free, S., and O’Sullivan, K. (2009) 'Warm homes: drivers of the demand for heating in the residential sector in New Zealand', Energy Policy, In Press, Corrected Proof, Available online 3 March 2009.

International Energy Agency (IEA). 1998. The Rebound Effect: A Review of U.S. Literature. Paris: International Energy Agency.

1999. Energy Use and Efficiency in New Zealand in an International Perspective: Comparison of Trends. through 1995. Paris: International Energy Agency and the Lawrence Berkeley National Laboratory

- 2004. Oil Crises \& Climate Challenges- 30 Years of Energy Use in IEA Countries. Paris: International Energy Agency.

- 2006. Energy Policies of IEA Countries: New Zealand 2006 Review. Paris: International Energy Agency.

—. 2006. World energy outlook 2006. Paris: International Energy Agency.

- 2007. Energy Policies of IEA Countries: Germany, Paris: International Energy Agency.

- 2008a. Promoting Energy Efficiency Investments: Case Studies in the Residential Sector, Paris: International Energy Agency.

—. 2008b. World Energy Outlook 2008, Paris: International Energy Agency.

- 2008c. IEA urges to overcome market barriers to increased energy efficiency in buildings, Paris: International Energy Agency.

Inhaber, H. 1997. Why energy conservation fails. Westport, Conn.: Quorum Books. 
Institut Wohnen und Umwelt (IWU). 2003. Deutsche Gebäudetypologie, Systematik und Datensätze, Darmstadt: Institut Wohnen und Umwelt.

Isaacs, N. (ed.), French, L. J. Camilleri, M. J. Pollard, A. R., Jowed, J. Fraser, R. Rossouw, P., Saville-Smith, K. 2006. Energy Use in New Zealand Households, Report on the 10 year Analysis for the Houshold Energy End-use Project (HEEP), Porirua: BRANZ.

Intergovernmental Panel on Climate Change (IPCC). 2007a. Fourth Assessment Report, Climate Change 2007 Synthesis Report, Geneva: Intergovernmental Panel on Climate Change.

- 2007b. Climate Change 2007: Mitigation of Climate Change, Working Group III contribution to the IPCC Fourth Assessment Report, Geneva: Intergovernmental Panel on Climate Change.

Jahn, D. 1998. Environmental performance and policy regimes: Explaining variations in 18 OECD-countries. Policy Sciences 31 (2):107-131.

Jahn, G. 1985. Antwort der Bundesregierung 94, Bundestagsdrucksache 10/3594, Bonn: Deutscher Bundestag.

Jänicke, M. 1992. Conditions for environmental policy success: An international comparison. The Environmentalist 12 (1):47-58.

Jordan, A. 2005. Environmental policy in the European Union. 2nd ed. London; Sterling, VA: Earthscan.

JPMorgan. 2007. Alternative Energy Strategy, New York: JPMorgan.

Katzenstein, P. J. 1977. Between Power and Plenty. Ithaca, N.Y.: Cornell University Press.

- 1985. Small states in world markets: industrial policy in Europe, Cornell studies in political economy. Ithaca, N.Y.: Cornell University Press.

— 1987. The Semisovereign State, Philadelphia: Temple University Press.

Kelsey, J. 1993. Rolling back the state: Privatisation of power in Aotearoa/New Zealand, Wellington, Bridget Williams Books.

Kreditanstalt für Wiederaufbau (KfW). 2008. Bauen, Wohnen, Energie sparen, Frankfurt: KfW, cited. available from http://www.kfwfoerderbank.de/DE_Home/Service/KfW-

Formul26/Merkblaetter/Bauen_Wohnen_Energie_sparen/index.jsp(acc essed 30.01.2009).

Khazzoom, J.D. 1987. Energy Savings Resulting from the Adoption of More Efficient Appliances. . The Energy Journal 1 (4):21-40.

Lehmbruch, Gerhard, and Philippe C. Schmitter. 1982. Patterns of corporatist policy-making, Sage modern politics series. London; Beverly Hills, Calif.: Sage Publications. 
Llewellyn, J. 2007. The Business of Climate Change, New York: Lehman Brothers Ltd.

Levine, L. E. 2006. How Many Legislators does it take to Change a Light Bulb Act. Sacramento: The California State Assembly.

Le Heron, R., Pawson, E. (Eds.) 1996. Changing Places: New Zealand in the Nineties, Auckland: Longman Paul.

Linden, A-L., Carlsson-Kanyama, A., Eriksson, B. 2005. Efficient and inefficient aspects of residential energz behaviour: What are the policy instruments for change?, Energy Policy, 34 (2006) 1918-1927.

List, Kevin. 2006. Key And Climate Change: 2005 vs. 2006, cited. available from http://www.scoop.co.nz/stories/HL0611/S00487.htm (accessed 01.11.2008).

Liphart, A. 1999. Patterns of Democracy: Government Forms and Performance in Thirty Six Countries. New Haven: Yale University Press.

Loewenich, G. 1991. Antwort der Bundesregierung, Frage 93, Bundestagsdrucksache 12/340, Bonn: Deutscher Bundestag.

Lomborg, B. 2002. The Environmentalists Are Wrong. The New York Times, August 26, 2002, cited. available from http://www.nytimes.com/2002/08/26/opinion/26LOMB.html (accessed 30.01.2009).

Lonergan, S.; Cocklin, C. 1990. In the aftermath of the energy crisis New Zealand's energy policy in the 1970s and 1980s. Energy Policy 18 (1):100-116.

Lovins, A. B. 1996. Negawatts : Twelve transitions, eight improvements and one distraction. Energy Policy 24 (4):331-343.

Lundqvist, L.1980. The hare and the tortoise : clean air policies in the United States and Sweden. Ann Arbor: University of Michigan Press.

McKay, M. 1975. New Zealand and the oil crisis - an examination of foreign policy reactions, Christchurch: University of Canterbury.

McCay, B. J., Acheson, J. M. (Eds.). 1987. Question of the Commons, The Culture and Ecology of Communal Resources Tucson: University of Arizona Press.

Merkel, A. 2005. Lasst uns mehr Freiheit wagen, Berlin: Federal Chancellor.

Merkel, A. 2007. A good day for Europe, Press conference of the German Presidency, Berlin: Foreign Office, cited. available from http://www.eu2007.de/de/Policy_Areas/index.html (accessed 05.07.2008).

Meadows, D. H., Meadows, D.I., Randers, J. Behrens, W.W. 1972. The Limits to Growth, A Report to the Club of Rome, New York: Universe. 
Ministry of Economic Development (MED). 2009. Take or Pay Contracts. Wellington: New Zealand Government, cited. available from http://www.med.govt.nz/templates/MultipageDocumentPage 5691 .aspx (accessed 30.05.2009)

Ministry for the Environment (MfE). 1992. New Zealand's National Report to the United Nations Conference on Environment and Development. Wellington: New Zealand Government.

- 2001. Valuing New Zealand's clean green image, Minister for the Environment. Wellington: New Zealand Government.

Mieterbund. 2008. Mieter für den Klimaschutz, cited. available from http://www.mieterbund.de/editorial_1208.html (accessed 23.04.2009)

Muldoon, R.D. 1977. Budget Debate edited by New Zealand House of Representatives.

National Party. 1981. We've got New Zealand going, Pamphlet prepared by the New Zealand National Party. Wellington: National Party.

Neumayer, E. Are left-wing party strength and corporatism good for the environment? Evidence from panel analysis of air pollution in OECD countries, Ecological Economics, Volume 45, Issue 2, June 2003, Pages 203-220.

New Zealand Herald. 1997. Rules to insulate homes from cold still delayed. New Zealand Herald, 23 August 1997.

Odum, H.T. 1981. New Zealand's Energy Economy Christchurch: University of Canterbury.

Organisation for Economic Co-operation and Development (OECD). 1989. Economic Survey New Zealand, Paris: Organisation for Economic Cooperation and Development.

- 2004. Economic Survey New Zealand, Paris: Organisation for Economic Co-operation and Development.

- 2008. Economic Survey New Zealand, Paris: Organisation for Economic Co-operation and Development.

- 2008. Economic Survey Germany, Paris: Organisation for Economic Co-operation and Development.

Offe, C., Keane, J. 1984. Contradictions of the welfare state, Contemporary politics. London: Hutchinson.

Olson, M. 1965. The logic of collective action; public goods and the theory of groups, Harvard economic studies, Cambridge, MA: Harvard University Press.

-1982. The rise and decline of nations : economic growth, stagflation, and social rigidities. New Haven: Yale University Press. 
Ostrom, E. 1990. Governing the Commons: The Evolution of Institutions for Collective Action, New York: Cambridge University Press.

., 1992, Crafting Institutions for Self-Governing Irrigation Systems, San Francisco: Institute for Contemporary Studies.

—., Dolšak, N. Stern, P., Stonich, S., Weber, E. 2002. The Drama of the Commons: Committee on the Human Dimensions of Global Change. Washington D.C. : National Research Council.

UNFCCC 2009. UN Data, cited. available from http://data.un.org/Data.aspx?q=co2+emission\&d=MDG\&f=seriesRow ID\%3a752 (accessed 12.05.2009)

Parker, D. 2007. Large investment in warmer, healthier homes, Wellington: New Zealand Government, cited. available from http://www.beehive.govt.nz/?q=node/29355(accessed 30.08.2008). 2008. Lights out for the incandescent bulb, Wellington: New Zealand Government, cited. available from http://www.beehive.govt.nz/release/lights+out+incandescent+bulb (accessed 15.05.2009).

Patterson, M.G. 1983. Estimation of the quality of energy sources and uses Energy Policy 11 (4):346-359.

Poel, B., van Cruchten, G. and Balaras, C. 2007. Energy performance assessment of existing dwellings. Energy and Buildings 39 (4):393403.

Rehdanz, K. 2006. Determinants of residential space heating expenditures in Germany, Energy Economics, 29 (2007): 167-182.

Reddy, A. 1991. Barriers to improvements in energy efficiency. Energy Policy 19 (10):953-961.

Röhling, E., Mohnfeld, J. 1985. Energy policy and the energy economy in FR Germany : An overview. Energy Policy 13 (6):535-545.

Rouni, G., Kirn, M. 2007. Efficient energy thermal insulation façade systems for optimal savings and flexibility in architectural design, Milos: International Workshop on Energy Performance and Environmental Quality of Buildings.

Scharpf, F. 1977. Politischer Immobilismus und ökonomische Krise: Aufsätze zu den politischen Restriktionen der Wirtschaftspolitik in der Bundesrepublik. Kronberg/Ts.: Athenäum.

Schettler-Koehler, H. 2007. Implementation of the EPBD in Germany Status October 2006. Bonn.

Schiffer, H-W. 1986. The changing energy market in FR Germany, 19731985, Energy Policy, 21 (2): 81-85. 
Schlegemilch, K. 2005. The Experiences with Green Budget Reform in the EZ and especially in Germany, Berlin: Federal Ministry for the Environment, Conservation and Nuclear Safety.

Schmidt, S. K. 2001. Die Einflussmöglichkeiten der Europäischen Union auf die Europäische Politik, Politische Vierteljahresschrift, 42 (2): 173192.

Schmidt, M. 2007. Das politische System Deutschlands: Institutionen, Willensbildung und Politikfelder, Bonn: Bundeszentrale für politische Bildung.

Schreurs, M. 2003. Environmental Politics in Japan, Germany, and the United States, Cambridge: Cambridge University Press.

Schuler, A., Weber, C, Fahl, U. 2000. Energy consumption for space heating of West-German households: empirical evidence, scenario projections and policy implications, Energy Policy, 28 (12): 877-894.

Scruggs, L. 2001. Is There Really a Link between Neo-Corporatism and Environmental Performance? Updated Evidence and New Data for the 1980s and 1990s. British Journal of Political Science 31 (4):686-692.

1999. Institutions and Environmental Performance in Seventeen Western Democracies. British Journal of Political Science 29 (1):1-31.

Smith, N. 2008. National's approach to energy efficiency costed and workable, Wellington: National Party, cited. available from http://www.national.org.nz/Article.aspx?articleId=28730 (accessed 30.05.2009).

Sontheimer, K. 1983. Zeitenwende? : die Bundesrepublik Deutschland zwischen alter und alternativer Politik. Hamburg: Hoffmann und Campe.

Sorrell, S. 2007. The Rebound Effect: an assessment of the evidence for economy-wide energy savings from improved energy efficiency, London: UK Energy Research Centre.

., Dimitropoulos, J., Sommerville, M. 2009. Empirical estimates of the direct rebound effect: A review, Energy Policy, Volume 37, Issue 4, April 2009, Pages 1356-1371.

Sperling, D. 1983. Mündliche Frage (oral question) 63 and 64, Bundestagsdrucksache 9/1904 Bonn: Deutscher Bundestag.

- 1985. Mündliche Frage (oral question) 94, Bundestagsdrucksache 10/3594, Bonn: Deutscher Bundestag.

Standards Association of New Zealand. 1977. Thermal Insulation. Standards in Progress, 2 (1977).

Statistisches-Bundesamt. 2006. Datenreport 2006 - Zahlen und Fakten über die Bundesrepublik, Bonn: Bundeszentrale für politische Bildung.

Stern, N. 2007. The Economics of Climate Change, London: H.M. Treasury. 
Stern, P. C., Dietz, T., Dolsak, N., Ostrom, E. and Stonich, S. in The Drama of the Commons, E. Ostrom et al., Eds. 2002. Washington, DC: National Academy Press, pp. 445-490.

Tainter, J. A. (1990). The Collapse of Complex Societies, Cambridge: Cambridge University Press.

Thompson, G. 1982. Statements in the NZ Parliament by Geoff Thompson MP (National Party member for Horowhenua): 4655, Hansard, Wellington: New Zealand House of Representatives.

Tiefensee, Wolfgang. 2008. Programme to reduce CO2 emissions from buildings has been a success in 2007. Berlin: Federal Ministry of Transport, Building and Urban Affairs, cited. available from http://www.bmvbs.de/en/-,1872.1027172/Tiefensee-Programme-toreduce-.htm (accessed 26.02.2009).

Time. 2007. Heroes of the Environment. Time, 02.10.2007, cited. available from http://www.time.com/time/specials/2007/article/0,28804,1663317_167 2378_1672379,00.html

Todd Energy. 2008. Maui field, Wellington: Todd Energy, cited. available from http://www.toddenergy.co.nz/te/pro_maui.html (accessed 30.05.2009).

Tourism New Zealand. 2008. Welcome to the youngest country on earth, Wellington: Tourism New Zealand, cited. available from http://www.newzealand.com/travel/International/(accessed 23.03.2009).

Thomsen, K., Wittchen K. 2008. European national strategies to move towards very low energy buildings, Aalborg: Danish Building Research Institute.

Treasury. 2005. Financial Statements of the Government of New Zealand, for the Eleven Months ended 31 May 2005. Wellington: New Zealand Treasury.

Umweltbundesamt (UBA). 2006. Hintergrundpapier, wie private Haushalte die Umwelt nutzen, Dessau: Umweltbundesamt.

United Nations Environment Programme (UNEP). 2008. Champions of the Earth Award Winners 2008, Geneva: UNEP, cited. available from http://www.unep.org/documents.multilingual/default.asp?documentid= 525\&articleid $=5738 \& 1=$ en (accessed 10.08.2008).

United Nations Framework Convention of Climate Change (UNFCCC). 2009. UN Data, Bonn: UNFCCC, cited. available from http://data.un.org/Data.aspx $\mathrm{q}=\mathrm{co} 2+\mathrm{emission} \& \mathrm{~d}=\mathrm{MDG} \& \mathrm{f}=$ =seriesRow ID\%3a752(accessed 10.08.2008).

Vattenfall. 2008. Vattenfall's approach to climate change, Stockholm: Vattenfall, cited. available from 
http://www.vattenfall.com/www/ccc/ccc/Gemeinsame_Inhalte/DOCU MENT/567263vattenfall/P0274659.pdf (accessed 10.08.2008)

Vogel, D. 2003. The Hare and the Tortoise Revisited: The New Politics of Consumer and Environmental Regulation in Europe. British Journal of Political Science, 33, (4) 557-580.

Vogel, D. 1986. National styles of regulation: environmental policy in Great Britain and the United States, Cornell studies in political economy. Ithaca: Cornell University Press.

Wilson, N., Horrocks, J. 2008. Lessons from the removal of lead from gasoline for controlling other environmental pollutants: A case study from New Zealand. Environmental Health 7 (1):1.

Wong, I., Eames, P., Perera, R. 2004. A review of transparent insulation systems and the evaluation of payback period for building applications, Solar Energy, Volume 81, Issue 9, September 2007, Pages 1058-1071.

World Energy Council (WEC). 2008. Energy Efficiency Policies around the World: Review and Evaluation, London: World Energy Council cited. available from http://www.worldenergy.org/documents/energyefficiency_final_online .pdf (accessed 10.04.2008)

Pictures (C) European Communities 
Oliver Lah: The Climate for Change

\section{APPENDICES}

